CEP Discussion Paper No 674

February 2005

\title{
The Impact of Training on Productivity and Wages: \\ Evidence from British Panel Data
}

Lorraine Dearden, Howard Reed and John Van Reenen

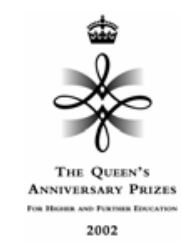




\begin{abstract}
It is standard in the literature on training to use wages as a sufficient statistic for productivity. But there are many reasons why wages and productivity may diverge. This paper is part of a smaller literature on the effects of work-related training on direct measures of productivity. We construct a panel of British industries between 1983 and 1996 containing training, productivity and wages. Using a variety of econometric estimation techniques (including system GMM) we find that training is associated with significantly higher productivity. Raising the proportion of workers trained in an industry by one percentage point (say from the average of $10 \%$ to $11 \%$ ) is associated with an increase in value added per worker of about $0.6 \%$ and an increase in wages of about $0.3 \%$. Furthermore, we find that the magnitude of the impact of training on wages is only half as large as the impact of training on productivity, implying that the existing literature has underestimated the importance of training. We also show evidence using complementary datasets (e.g. from individuals) that is suggestive of externalities of training and imperfect competition.
\end{abstract}

Keywords: Productivity, training, wages, panel data

JEL Classifications: J31; C23; D24

This paper was produced as part of the Centre's Productivity and Innovation Programme. The Centre for Economic Performance is financed by the Economic and Social Research Council.

\title{
Acknowledgements
}

Financial support from the Economic and Social Research Council and the Leverhulme Trust, is gratefully acknowledged. The authors would like to thank Fernando Galindo-Ruedo, Amanda Gosling, Richard Layard, Lisa Lynch, Steven McIntosh, Stephen Machin, Alan Manning, Steve Pischke, two anonymous referees and participants in many seminars for helpful comments. We are grateful to the Office for National Statistics for supplying the Census of Production data and to the OECD for supplying the ISDB data. We would like to thank Martin Conyon for supplying the firm level training data and Jonathan Haskel for providing us with some of the industry price indices used in the paper. Material from the Labour Force Survey is Crown Copyright; have been made available by the Office for National Statistics through the ESRC Data Archive and has been used by permission. Neither the ONS nor the Data Archive bear any responsibility for the analysis or interpretation of the data reported here. An earlier version of this paper (with a longer data description) has appeared as "Who Gains when Workers Train" Institute for Fiscal Studies Discussion Paper No. 00/04.

Lorraine Dearden is Director of the Centre for Early Years and Education Research (CEYER) at the Institute for Fiscal Studies. Howard Reed is Research Director at the Institute for Public Policy Research (IPPR). John Van Reenen is Director of the Centre for Economic Performance, London School of Economics. He is also a Research Fellow for CEPR.

Published by

Centre for Economic Performance

London School of Economics and Political Science

Houghton Street

London WC2A 2AE

All rights reserved. No part of this publication may be reproduced, stored in a retrieval system or transmitted in any form or by any means without the prior permission in writing of the publisher nor be issued to the public or circulated in any form other than that in which it is published.

Requests for permission to reproduce any article or part of the Working Paper should be sent to the editor at the above address.

(C) L. Dearden, H. Reed and J. Van Reenen, submitted 2005

ISBN 0753018144 


\section{Introduction}

It is a widely-held view that Britain needs to increase work-related training to improve long-term economic performance and address the "skills gap". 1 Despite the policy interest and the huge economics literature on human capital there are hardly any papers that examine the impact of work-related training on direct measures of productivity. The primary contribution of our paper is to provide such evidence for the first time in the UK and for the first time anywhere over a long period (about 14 years). Analysis of the impact of training on productivity has focused almost entirely on estimating the impact of training on wages. Most studies looking at the private return to work-related training find that training results in workers receiving higher real wages ${ }^{2}$.

Although these studies are informative, they only tell half the story as they ignore the impact on the employer's productivity. The relationship between wage increases and productivity gains can vary according to the structure of the labour and product markets and according to who actually pays the costs of training. In the simplest neoclassical view of the labour market where the market is perfectly competitive wages will be equal to the value of marginal product. Thus the wage can be taken as a direct measure of productivity. This simple relationship can break down for many reasons. For example, in Becker's model of specific human capital the employer will pay for training so there should be no effect of completed training spells on observed wages even though there may be a large impact on productivity ${ }^{3}$.

\footnotetext{
${ }^{1}$ See Green and Steedman (1997) or National Skills Task Force (1998). In the December 2003 PreBudget Report, the British Chancellor justified the extension of the Employer Training Pilots in order to help improve the skills gap and UK productivity.

(http://www.hm-treasury.gov.uk/media//2E3BD/03_Meeting\%20the\%20Pro_EF.pdf)

${ }^{2}$ See Greenhalgh and Stewart (1987), Booth $(1991,1993)$ or Blundell et al (1996) for UK evidence. US studies using panel data include Lillard and Tan (1992), Lynch (1992), Blanchflower and Lynch (1992) and Bartel and Sicherman (1999). Winkelmann (1994) uses German data and Bartel (1995) looks within a large US manufacturing company.

${ }^{3}$ There are many other reasons for a wedge between productivity and wage in a competitive labour market. First, employees may receive non-pecuniary benefits from training. Second, workers may
} 
If the labour market is characterised by imperfect competition then the strict link between wages and productivity is usually broken. Employees can find themselves being paid less (or more) than their marginal revenue product. Nevertheless it is still the case that conditional on a given degree of rentsharing or monopsony power increases in wages have to be paid out of productivity gains. Therefore we can assert the general principle that these real wage increases should provide a lower bound on the likely size of productivity increases. In practice the productivity gains are likely to be higher than this. For instance, in a labour market with frictions and some wage compression (e.g. from a binding minimum wage) there will be productivity gains even from general training that are not passed on to the employee in terms of wages but are only reflected in direct measures of productivity ${ }^{4}$. Similar results can be found in some bargaining models (e.g. Booth et al, 1999).

There exist a small number of empirical papers that relate firm productivity to a measure of training ${ }^{5}$. Although a positive correlation is generally found, it is very difficult to interpret because the training measures are only measured at a single point of time and could be picking up many unobservable firm specific factors correlated with both training and productivity. Black and Lynch (2001) use an establishment training survey at two points of time. In the cross section they identified some effects of the type of training on productivity, but they found no significant association when they controlled for plant specific effects. Ichinowski et al (1997) investigate what affects productivity in a panel of US

implicitly pay the costs of a training scheme the form of lower wages whilst being trained, which then rise after training is completed - so we might see a greater increase in observed wages than in productivity. Third, employees' wages could be lower during training because they are not contributing to firm productivity whilst actually being trained. Fourth, there may be deferred compensation packages where the employee's remuneration is 'backloaded' towards later post-training years as a means of ensuring loyalty and/or effort early in the employee's tenure (e.g. Lazear, 1979).

${ }^{4}$ See Acemoglu and Pischke $(1999,2003)$.

5 Black and Lynch (1996), Bartel (1994), Barrett and O’Connell (2001), de Koning (1994), Boon and ven der Eijken (1997) and Ballot and Taymaz (1999) have objective productivity measures. Bartel (1995), Holzer (1990) and Barron, Black and Lowenstein (1989) and Krueger and Rouse (1998) use subjective measures of productivity. Holzer et al (1993) do find effects of changes in productivity on changes in one measure of quality - the scrap rate. 
steel finishing mills. After controlling for fixed effects they found a role for training only in combination with a large variety of complementary human resource practices. Carriou and Jeger (1997), Ballot et al (1998) and Delame and Kramarz (1997) use French firm level panel data to look at the effects of training on value added and find positive and significant effects. Although these studies are broadly consistent with our own they do not fully exploit the potential of their panel data by allowing training to be a choice variable ${ }^{6}$.

Our contribution in this paper is to advance the literature in at least three ways. Black and Lynch (2001) emphasise the problems of trying to identify the effects of training in a short panel (they have only two separate training observations). Although unobserved heterogeneity can be controlled for through fixed effects with only two periods, attenuation biases due to measurement error are exacerbated. To address this, we build a panel that contains up to fourteen consecutive years of training data. Second, we explicitly allow training to be a choice variable by using General Method of Moments (GMM) estimators developed to deal with endogenous variables in production functions. Thirdly, we combine estimation of the productivity effects of training with estimation of the wage effects of training. Although comparisons between the production function and the wage equation are becoming more common for other worker characteristics such as gender and human capital this is the first time the strategy has been used for training ${ }^{7}$. In principle this allows us to examine whether trained workers are paid the value of their marginal product.

We conduct our main analysis of the effects of training at the industry level, rather (although we perform estimation at the firm and individual level for comparative purposes). There is simply no alternative to this strategy if one wishes to use long time series of training and productivity information. The

\footnotetext{
${ }^{6}$ See Greenhalgh (2002) for a much more extensive review of the French and UK literature in this area. ${ }^{7}$ Hellerstein, Neumark and Troske et al (1999), Hellerstein and Neumark (1999), Haegler and Klette (1999) and Jones (2001) examine the differential impact of human capital and gender on wages and productivity. A recent study which utilises our methodology and looks at this question using a panel of French and Swedish firms is Ballot et al $(2001,2002)$. They find that in both France and Swedish firms appropriate a high proportion of the returns to training ( 82 and 67 per cent respectively).
} 
only publicly available firm level panel data in the UK is a sample of about 119 firms in the late 1990s with only very basic training information (a concise investigation of this is presented in Appendix B). Aggregation has pros and cons that are discussed in the paper. On the positive side, if there are important spillovers to training within an industry (e.g. through a faster rate of innovation) then a firm level analysis will potentially miss out these linkages and underestimate the return to human capital ${ }^{8}$. On the negative side, there may be aggregation biases at the sectoral level that could lead to negative or positive biases on the training coefficient. We follow Grunfeld and Griliches (1960) in arguing that the pros outweigh the cons.

The format of the paper is as follows. Section 2 describes the simple economic models of productivity and wages that we will estimate and section 3 details the econometric strategy. The data are described in section 4 and the results are presented in section 5. Section 6 offers some concluding comments. The Appendices contain more information on the data and some additional experiments. Our main result is that we find a statistically and economically significant effect of training on industrial productivity. A 1 percentage point increase in training is associated with about a 0.6 percent increase in productivity and a 0.3 per cent increase in hourly wages. The productivity effect of training is twice as large as the wage effect, implying that existing studies have underestimated the benefits of training by focusing on wages.

\footnotetext{
${ }^{8}$ For example, O'Mahony (1998) finds that the coefficient on labour skills in a production function is more than twice that assumed by traditional growth accounting from relative wages. Other recent papers which have looked at the impact of human capital on directly measured productivity include Moretti (2004) on U.S. data and Haskel, Hawkes and Pereira (2003) on U.K. data.
} 


\section{A Model of training and productivity}

To see our approach assume that we can characterise a representative plant in an industry by a Cobb-Douglas production function written in value added form ${ }^{9}$

$$
Q=A L^{\alpha} K^{\beta}
$$

where $Q$ is value added, $L$ is effective labour input allowing for quality and quantity dimensions, $K$ is capital and $A$ is a Hicks neutral efficiency parameter.

We consider that trained workers are more productive than untrained workers, so that effective labour input can be written as

$$
L=N^{U}+\gamma N^{T}
$$

where $N^{U}$ are the number of untrained workers, $N^{T}$ are trained workers and $\gamma$ is a parameter which, if trained workers are more productive than non-trained workers, will be greater than unity. The total number of workers, $N$, is equal to the sum of trained and untrained workers. Substituting equation (2) into equation (1) gives:

$$
Q=A(1+(\gamma-1) T R A I N)^{\alpha} N^{\alpha} K^{\beta}
$$

Where TRAIN $=N^{T} / N$, is the proportion of trained workers in an industry. Taking natural logarithms, we obtain

$$
\ln Q=\ln A+\alpha \ln (1+(\gamma-1) T R A I N)+\alpha \ln N+\beta \ln K
$$

This could be estimated by non-linear least squares. If $(\gamma-1)$ TRAIN is "small" we can use the approximation $\ln (1+x)=x$ and re-write the production function as $^{10}$ : 


$$
\ln Q=\ln A+\alpha(\gamma-1) T R A I N+\alpha \ln N+\beta \ln K
$$

If the industry exhibits constant returns to scale (i.e. $\alpha+\beta=1$ ) then equation (5) can be re-written in terms of labour productivity as

$$
\ln (Q / N)=\ln A+(1-\beta)(\gamma-1) T R A I N+\beta \ln (K / N)
$$

If the trained are no more productive than the untrained $(\gamma=1)$ then the coefficient on TRAIN will be zero.

This method can be easily extended to a larger number of different types of heterogeneous workers in the labour quality index. If we index the discrete type of labour by $k$ (where until now we have discussed $k$ solely in terms of the training status of workers) then equation (4) can be written

$$
\ln Q=\ln A+\alpha \ln \left(1+\sum_{k}\left[\left(\gamma_{k}-1\right)\left(N_{k} / N\right)\right]+\alpha \ln N+\beta \ln K\right.
$$

Empirically we will allow for many other dimensions of labour quality such as education, occupation, age, tenure and gender ${ }^{11}$. There are a large number of other influences on productivity captured in $A$ so we allow for differential hours, worker turnover rates, innovation (as proxied by research and development expenditures), regional composition and the proportion of small firms. Labeling these factors as $X$, imposing constant returns and using the log approximation the basic production function becomes:

\footnotetext{
${ }^{9}$ This should be viewed as a first order approximation to a more complicated functional form. It is straightforward to generalize this to more complex functional forms such as translog and some experiments are included in the empirical results.

${ }_{10}$ The results were estimated both by non-linear least squares and by least squares using the approximation. The results did not significantly differ (see Table 3), so the more convenient log linear approximation is used for the baseline results.

${ }^{11}$ We follow Hellerstein et al (1999) by entering these variables in linear proportions. One could allow a larger number of cells for interactions of the labour quality variables (e.g. the proportion of educated men - a two way interaction, or the proportion of educated men who are trained - a three way interaction). We experimented with some breakdowns like this on the training variable, but LFS cell sizes by industry were generally not large enough.
} 


$$
\ln (Q / N)=(1-\beta) \sum_{k}\left[\left(\gamma_{k}-1\right)\left(N_{k} / N\right)\right]+\beta \ln (K / N)+\delta^{\prime} X
$$

The wage equation that we estimate parallels the productivity equation in (8). We view the wage equation as more of a descriptive regression than the structurally derived production function. Under competitive spot markets for labour relative wages should equal the relative marginal productivities of workers of different types. This is because if the relative productivity of trained workers $(\gamma)$ exceeded the relative wages of trained workers then employers would only employ trained workers (Hellerstein et al, 1999).

Consider the wage bill $(W)$ for the representative plant in an industry. Again, take the simplest model where there are only two types of workers: trained workers paid average wage $w^{T}$ and untrained workers paid average wage $w^{N T}$. Relative wages are $\lambda=w^{T} / w^{N T}$. By definition,

$$
W=w^{N T}\left(N-N^{T}\right)+\lambda w^{N T} N^{T}=w^{N T}\left(N+(\lambda-1) N^{T}\right)
$$

In logarithms, the average wage $(w)$ is

$$
\ln w=\ln (W / N)=a+\ln (1+(\lambda-1) T R A I N)
$$

where $a=\ln w^{N T}$

Clearly the coefficient on training can be used to recover the relative wage mark up associated with training $(\lambda)$ and then compared to the relative productivity effect $(\gamma)$. Parallel to the productivity equation we will allow for multiple type of labour quality and other factors to influence wages. The empirical wage equation to be estimated is therefore ${ }^{12}$ :

\footnotetext{
${ }^{12}$ One could argue that firm variables such as capital intensity and R\&D should be excluded from the wage equation under competitive labour markets. However, these variables are typically quite informative in wage equations either because they are picking up some measure of unobserved labour quality (Hellerstein and Neumark, 1999) or because of departures from perfect competition. In either
} 


$$
\ln w=\sum_{k}\left[\left(\lambda_{k}-1\right)\left(N_{k} / N\right)\right]+\beta^{w} \ln K+\delta^{w} X
$$

\section{Econometric Modeling Strategy}

The basic equation we wish to estimate can be written in simplified form as

$$
y_{i t}=\theta x_{i t}+u_{i t}
$$

where $y$ is $Q / N$, and $x$ is a vector of (suspected endogenous) variables including training. Subscript $i$ indicates the representative firm in an industry $t$ is time and $\theta$ is the parameter of interest. Assume that the stochastic error term, $u_{i t}$, takes the form

$$
\begin{aligned}
& u_{i t}=\eta_{i}+\tau_{t}+\omega_{i t} \\
& \omega_{i t}=\rho \omega_{i t-1}+v_{i t}
\end{aligned}
$$

The $\tau_{t}$ represent macro economic shocks captured by a series of time dummies, $\eta_{i}$ is an individual effect, and $v_{i t}$ is a serially uncorrelated mean zero error term. The other element of the error term, $\omega_{i t}$ is allowed to have an $\mathrm{AR}(1)$ component (with coefficient $\rho$ ) which could be due to measurement error or slowly evolving technological change Substituting (13) into (12) gives us the dynamic equation

$$
y_{i t}=\pi_{1} y_{i t-1}+\pi_{2} x_{i t}+\pi_{3} x_{i t-1}+\eta^{*}{ }_{i}+\tau^{*}{ }_{t}+v_{i t}
$$

The common factor restriction (COMFAC) is $\pi_{1} \pi_{2}=-\pi_{3}$. Note that $\tau^{*}{ }_{t}=\tau_{t}-\rho \tau_{t-1}$ and $\eta_{i}^{*}=(1-\rho) \eta_{i}$. 
In main results section we present several econometric estimates of production functions (random effects, within groups and GMM). The most rigorous approach follows that recommended by Blundell and Bond (2000) that uses a "system GMM" approach to estimate equation (14) and then imposes the COMFAC restrictions by minimum distance. We now turn to describing the GMM approach in more detail.

How should equation (14) be estimated? If training is strictly exogenous and there are no dynamics (i.e. $\rho=0$ ), then the only problem with OLS estimation of (12) is the presence of the individual effects, $\eta_{i}$. If these individual effects are uncorrelated with $x_{i t}$ then the random effects estimator is unbiased and efficient. If the individual effects are correlated with $x_{i t}$ but remain strictly exogenous then although the random effects estimator is biased, the within group estimator will be unbiased.

If we allow training to be endogenous (i.e. allowing training decisions to react to shocks to current productivity) we will require instrumental variables. In the absence of any obvious natural experiments we consider moment conditions that will enable us to construct a GMM estimator for equation (14). A common method would be to take first differences of (14) to sweep out the fixed effects:

$$
\Delta y_{i t}=\pi_{1} \Delta y_{i t-1}+\pi_{2} \Delta x_{i t}+\pi_{3} \Delta x_{i t-1}+\Delta \tau_{t}+\Delta v_{i t}
$$

Since $v_{i t}$ is serially uncorrelated the moment condition

$$
E\left(x_{i t-2} \Delta v_{i t}\right)=0
$$

ensures that instruments dated $t-2$ and earlier ${ }^{13}$ are valid and can be used to construct a GMM estimator for equation (14) in first differences (Arellano and Bond, 1991). A problem with this estimator is that variables with a high degree of persistence over time (such as capital) will have very low correlation between their first difference $\left(\Delta x_{i t}\right)$ and the lagged levels being used an

\footnotetext{
${ }^{13}$ Additional instruments dated t-3, t-4, etc. Become available as the panel progresses through time.
} 
instrument (e.g. $x_{i t-2}$ ). This problem of weak instruments can lead to substantial bias in finite samples.

Blundell and Bond (1998) point out that under a restriction on the initial conditions another set of moment conditions are available ${ }^{14}$ :

$$
E\left(\Delta x_{i t-1}\left(\eta_{i}+v_{i t}\right)\right)=0
$$

This implies that lags of the first differences of the endogenous variables can be used to instrument the levels equation (14) directly. The econometric strategy is then to combine the instruments implied by the moment conditions (16) and (17). We stack the equations in differences and levels (i.e. (14) and (15)). We can obtain consistent estimates of the coefficients and use these to recover the underlying structural parameters in (12).

The estimation strategy assumes the absence of serial correlation in the levels error terms $\left(v_{i t}\right)^{15}$. We report serial correlation tests in addition to the Sargan-Hansen test of the over-identifying restrictions in all the GMM results below ${ }^{16}$.

This GMM "system" estimator has been found to perform well in Monte Carlo simulations (Blundell and Bond, 1998) and in the context of the estimation of production functions (Blundell and Bond, 2000). The procedure should also be a way of controlling for transitory measurement error (the fixed effects control for permanent measurement error). Random measurement error has been found to be a problem in the returns to human capital literature, typically generating attenuation bias (see Card, 1999).

\footnotetext{
14 The conditions are that the initial change in productivity is uncorrelated with the fixed effect $E\left(\Delta y_{i 2} \eta_{i}\right)=0$ and that initial changes in the endogenous variables are also uncorrelated with the fixed effect $E\left(\Delta x_{i 2} \eta_{i}\right)=0$

${ }^{15}$ If the process is MA(1) instead of MA(0) then the moment conditions in (16) and (17) no longer hold. Nevertheless $E\left(x_{i t-3} \Delta v_{i t}\right)=0$ and $E\left(\Delta x_{i t-2}\left(\eta_{i}+v_{i t}\right)\right)=0$ remain valid so earlier dated lags could still be used as instruments. This is the situation empirically with the wage equations.

${ }^{16}$ These are based on the first differenced residuals so we expect significant first order serial correlation but require zero second order serial correlation for the instruments to be valid. If there is significant second order correlation we need to drop the instruments back a further time period (this happens to be the case for the wage equation in the results below).
} 
In order to assess the importance of biases associated with fixed effects and endogeneity we will estimate random effects, within groups and GMM estimates in the results section.

Finally, consider two more issues which are harder to deal with: aggregation and training stocks vs. training flows. Estimation at the three digit industry level has advantages but also disadvantages relative to micro-level estimation. The production function in equation (1) at the firm level describes the private impact of training on productivity. However, many authors, especially in the endogenous growth literature (e.g. Aghion and Howitt, 1998), have argued that there will be externalities to human capital acquisition. For example, workers with higher human capital are more likely to generate new ideas which may spill over to other firms ${ }^{17}$. If spillovers are industry specific this implies that there should be additional terms added to equation (5) representing training in other firms (e.g. the mean number of trained workers in the industry). In this case the coefficient on training in an industry level production function should exceed that in a firm level production function ${ }^{18}$. Secondly, grouping by industry may smooth over some of the measurement error in the micro data and therefore reduce attenuation bias.

On the negative side, there may be aggregation biases in industry level data. A priori it is not possible to unambiguously sign these biases. We expect that the fixed effects will control for some of the problem. For example, we are taking logs of means and not the means of logs in aggregating equation (4), but so long as the higher order moments of the distributions are constant over time in an industry then they will be captured by a fixed effect ${ }^{19}$. If the coefficients are not constant across firms in equation (4), but are actually random, this will also generate higher order terms at the industry level. In the

\footnotetext{
17 Although there are many papers which examine externalities of R\&D (e.g. see the survey by Griliches, 1992) and a few which look at human capital (Acemoglu and Angrist, 2000 and Moretti, 1999) there are none that focus on training spillovers.

${ }^{18}$ For the same argument in the R\&D context see Griliches (1992)

${ }^{19}$ If they evolve at the same rate across industries they will be picked up by the time dummies.
} 
empirical results we experiment with including higher order moments and allowing the coefficients to vary across cross sectional units.

Turning to the problem of training stocks and flows, note that the model in equation (1) assumes that we know the stocks of trained workers in an industry. What we actually have in the data is an estimate of the proportion of workers in an industry who received training in a given 4-week period (the training flow). Since individuals are sampled randomly over time in the LFS this should be an unbiased estimate of the proportion of people in training in given industry in a given $\operatorname{year}^{20}$. As an alternative to using the flow we calculate a stock of training in an analogous way to using investment flows to calculate a capital stock through the perpetual inventory method (the main form of depreciation is the turnover rate). This is described in the Data Appendix.

\section{Data Description}

The database we construct combines several sources (see Data Appendix for full details). The critical individual level source is the individual level UK Labour Force Survey (LFS) which contained about 60,000 households per year. Most importantly, the LFS has a consistent training measure since 1984 as well as detailed information on skills, demographics, hours worked, tenure and wages. We work with this information aggregated by broadly three digit industries. The LFS only started asking questions on wages at two points of time in 1997 (and at one point of time in 1992 when the panel was set up). We present some individual level panel wage regressions at the end of section 5 for comparison.

The second major dataset we use is the Annual Census of Production (ACOP). This gives production statistics on capital, wages, labour and output

\footnotetext{
${ }^{20}$ If there are many multiple training spells in the month we will underestimate the proportion of employees who are being trained. If Spring (the LFS quarter we use) is a particularly heavy training season then we will overestimate the proportion being trained in a year. These biases are likely to be small and offsetting.
} 
for industries in the production sector (manufacturing, mining and utilities). For the services industries we drew on the OECD's ISDB data.

There was a change in SIC classification in 1992 which forced us to aggregate some of the industries and prevented us from using some of the industries after the change. Additionally, we insisted on having at least 25 individuals in each cell in each year. After matching the aggregated individual data from LFS we were left with 94 industry groupings over (a maximum of) 14 years.

The main LFS training question was, "over the 4 weeks ending Sunday ... have you taken part in any education or training connected with your job, or a job that you might be able to do in the future?"21 The average proportions of employees undertaking training grew steadily from about $8 \%$ in 1984 to $14 \%$ in 1990 where it stabilized for the next 6 years. Most of this growth was upgrading within industry rather than between industries ${ }^{22}$.

Figure 1 gives the scatterplot of labour productivity (log real value added per worker) against training propensity and Figure 2 repeats the exercise for log hourly wages. Unsurprisingly training has a strong positive correlation with both variables, but the association is somewhat weaker for wages than for productivity.

The outliers in both graphs tend to be in the service sector. Unfortunately, the published series for real value added and capital stocks are rather unreliable in the service sector. For example in banking and financial services measured real value added per person declined every year between 1983 and 1996. Given the poor quality of the service sector production data we reluctantly decided to focus the econometric part of the analysis on the production side of the economy. This is still a substantial share of the economy about $50 \%$ of

\footnotetext{
${ }^{21}$ Unfortunately it is not possible to separate out "education" from "training".

${ }^{22}$ There is also a question of the length of the training spell, but this was only asked in particular years and there were too many missing values to use it as a separate regressor. Median spell length was two weeks and the mean higher.
} 
private sector net output in $1986 .{ }^{23}$ Until robust measures of service sector productivity are developed there is simply no alternative to the empirical strategy of focusing on the production sector.

Care must be taken in interpreting the scatterplots presented in Figures 1 and 2 as they say nothing about the causal impact of training on productivity or wages. Table A1 in the Data Appendix shows that high training industries are characterized by higher fixed capital intensity, more professional workers, more educated workers and higher R\&D. We need to turn to an explicit econometric model to investigate whether there is a causal effect of training on productivity and this forms the focus of the rest of the paper.

\section{Results}

\subsection{Baseline Industry Results}

In Table 1 we present the basic results for the industry-level regressions treating all variables as exogenous. The first three columns have productivity (log real value added per head) as the dependent variable and the last three columns have wages as the dependent variable.

\footnotetext{
23 This lead to the loss of only 91 observations and the results are robust to including the service sector in the unweighted regressions. We generally weight the regressions by the number of LFS observations in order to reduce sampling variability. In the weighted regressions including the service sector does have more substantial effects on the results because of their large employment shares. Full sets of these results are available on request from the authors.
} 
Figure 1: Labour Productivity and Training in British Industries

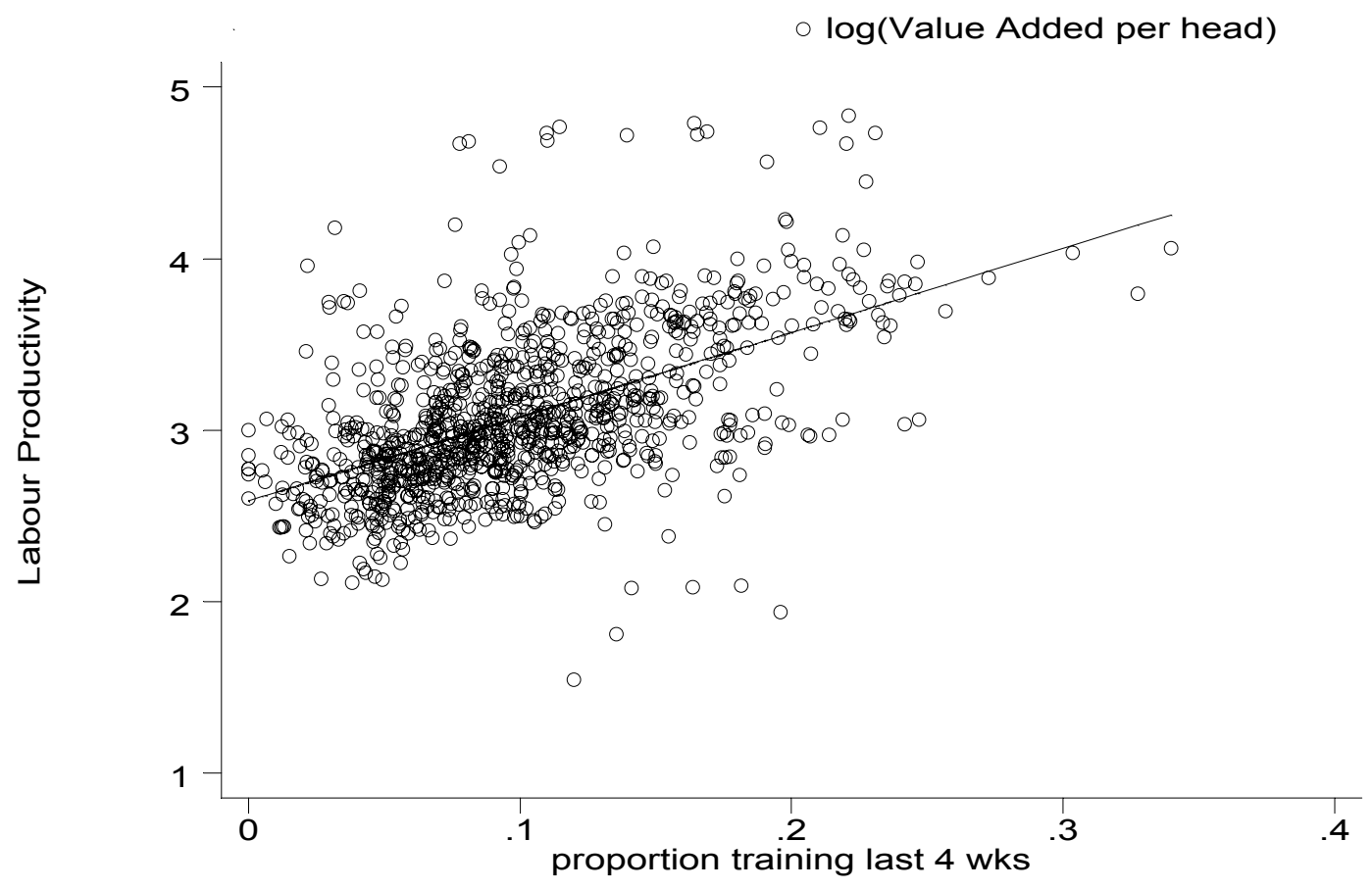

Figure 2: Wages and Training in British Industries

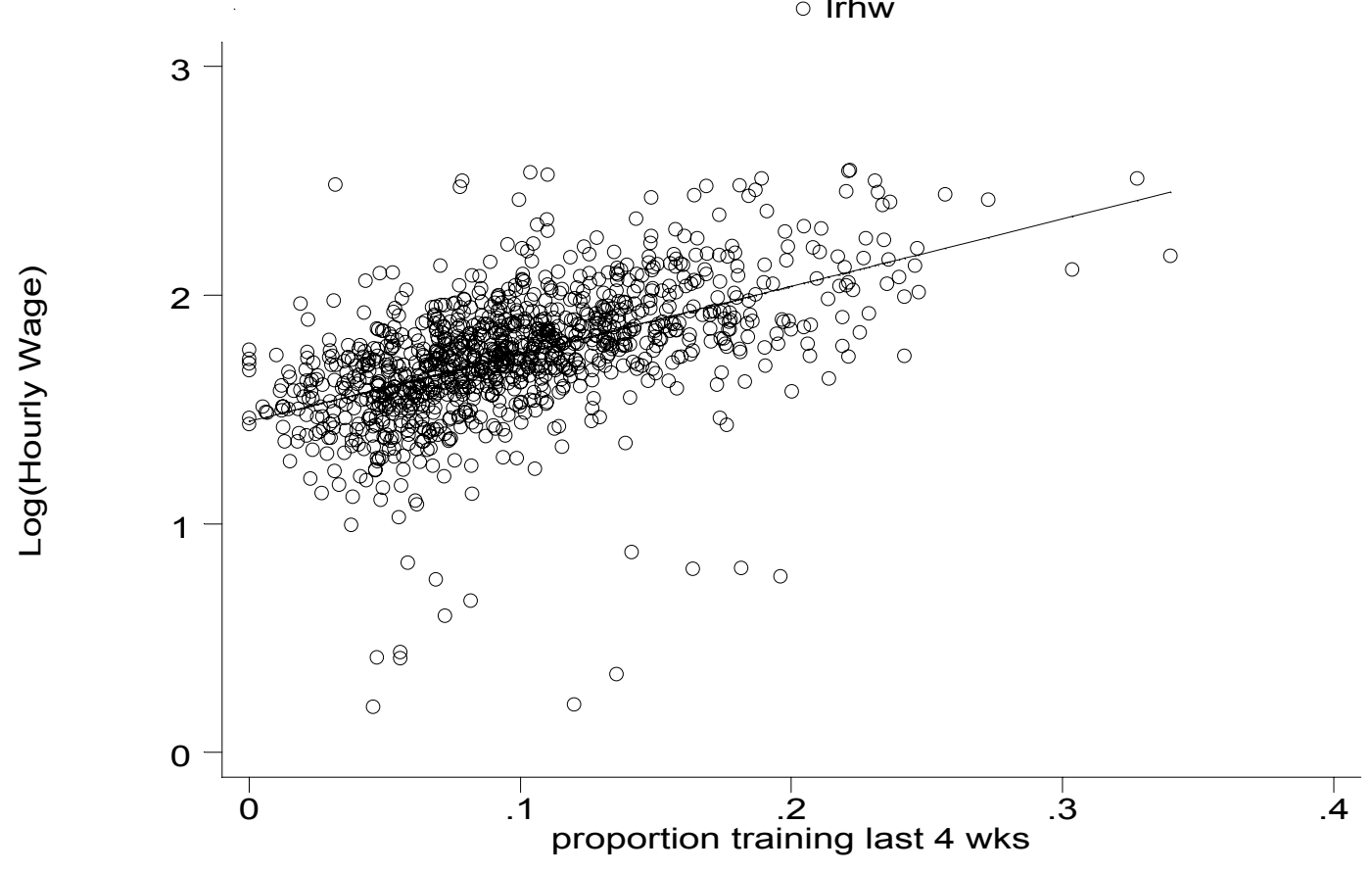

Notes to Figures 1 and 2

Each point is an industry-year observation; the OLS regression line has a slope of 4.91 for productivity and 2.95 for wages; labour productivity is $\log$ (Value added per employee); Wages are log hourly wages from the Census of Production (wages) and the LFS (hours); training is the proportion of workers involved in training from the LFS 
The first two columns are estimated by random effects; the only difference is that column (1) does not include the occupational controls. This makes some difference to the "no qualifications" variable which has a significantly negative association with productivity in the first column, but is insignificantly different from zero in the second column - the occupational proportions (especially the professional/managerial category)) do a better job at proxying for workforce skill than education ${ }^{24}$. The variables generally take their expected signs, although it is clear that there is some loss of precision when a full set of fixed effects is added in column (3). Capital per worker is strongly correlated with productivity, although the coefficient is lower $(0.21$ to 0.25$)$ than capital's share of value added which is about $30 \%$. Worker turnover has a significantly negative association with productivity and R\&D a significantly positive correlation. Younger workers (aged between 16 and 24) are significantly less productive than the 35-45 year old group.

Most importantly for our purposes, training has a statistically significant and economically important effect on productivity according to Table 1. The magnitude of the coefficient falls as we move to the more rigorous specification that controls for fixed effects, but the change is not dramatic. The estimates imply that raising the training variable by 1 percentage point (say from the 1996 economy wide mean of about $14 \%$ to $15 \%$ ) is associated with an increase in productivity of about $0.7 \%$. We will return to the plausibility of the magnitude of these effects in sub-section 5.3.

The last three columns repeat the specifications but instead use In(earnings) as the dependent variable. The most interesting contrast for our purpose is the coefficient on training. As with productivity, training enters the earnings equation with a consistently positive and significant coefficient across all three columns. The magnitude of the coefficient in the wage equation is much lower

\footnotetext{
${ }^{24}$ This conclusion does not change if we break down the qualifications into four groups. Machin et al (2003) adopt a much finer classification of education using post 1992 LFS data where there are a larger number of observations. Exploiting the regional and industry aspect of the aggregated data they find some role for college proportion, even in fixed effect specifications.
} 
than in the productivity equation - just under half the size, in fact. On face value, then, estimating the returns to training solely on the basis of wage equations would generate an under-estimate of the importance of workrelated training ${ }^{25}$.

Turning to the other variables in the wage equation, the signs of most of the variables are the same as those in the productivity equations, although there are some differences. As expected, earnings are significantly higher in more capital intensive, hours intensive and highly skilled industries. The R\&D coefficient is surprisingly negative (although insignificantly different from zero), but this turns out to be because of mis-specified dynamics - including longer lags of R\&D demonstrates there is actually a positive correlation of technology with wages ${ }^{26}$ (see Table 2).

An important concern with Table 1 is that we do not allow for the endogeneity of training or other suspected endogenous variables. To deal with this we implemented the GMM approach described in section 3 above. Table 2 contains a summary of the main results ${ }^{27}$. All the same variables are included in these regressions as in Table 1 , but we report only the key coefficients to preserve space.

\footnotetext{
${ }^{25}$ Explicit tests of the equality of the coefficients on training in the wage and productivity equations was rejected at the .10 level for training $(p$-value $=.068)$. This calculation allows for correlation between the wage equation and the production function using Seemingly Unrelated Regression (note that jointly estimating by SUR is no more efficient than OLS in this context because all independent variables enter both equations). The equality of coefficients on $R \& D$, turnover and capital intensity was also rejected at the 0.05 level.

${ }^{26}$ Consistent with the findings of inter alia Bartel and Sicherman (1999)

27 Data Appendix Table B2 has more detailed results and even more detailed specifications are available from authors or in Dearden et al (2000)
} 
Table 1 Training, Productivity and Wages

\begin{tabular}{|c|c|c|c|c|c|c|}
\hline & (1) & (2) & (3) & (4) & (5) & (6) \\
\hline & \multicolumn{3}{|c|}{ Ln(Value added per worker) } & \multicolumn{3}{|c|}{ Ln(Wages) } \\
\hline & $\begin{array}{l}\text { Random } \\
\text { Effects }\end{array}$ & $\begin{array}{l}\text { Random } \\
\text { Effects }\end{array}$ & Within Groups & $\begin{array}{l}\text { Random } \\
\text { Effects }\end{array}$ & $\begin{array}{l}\text { Random } \\
\text { Effects }\end{array}$ & Within Groups \\
\hline Training & $\begin{array}{c}.788 \\
(.168)\end{array}$ & $\begin{array}{l}.700 \\
(.169)\end{array}$ & $\begin{array}{c}.696 \\
(.201)\end{array}$ & $\begin{array}{c}.425 \\
(.117)\end{array}$ & $\begin{array}{l}.344 \\
(.119)\end{array}$ & $\begin{array}{l}.365 \\
(.157)\end{array}$ \\
\hline $\log$ (capital/worker) & $\begin{array}{c}.252 \\
(.020)\end{array}$ & $\begin{array}{c}.244 \\
(.019)\end{array}$ & $\begin{array}{c}.212 \\
(.053)\end{array}$ & $\begin{array}{c}.058 \\
(.012)\end{array}$ & $\begin{array}{c}.051 \\
(.012)\end{array}$ & $\begin{array}{c}.069 \\
(.035)\end{array}$ \\
\hline $\log ($ hours/worker) & $\begin{array}{l}.184 \\
(.181)\end{array}$ & $\begin{array}{l}.196 \\
(.181) \\
\end{array}$ & $\begin{array}{c}.275 \\
(.207)\end{array}$ & $\begin{array}{c}.274 \\
(.123)\end{array}$ & $\begin{array}{c}.272 \\
(.126)\end{array}$ & $\begin{array}{c}.310 \\
(.116)\end{array}$ \\
\hline $\begin{array}{l}\text { Lagged R\&D } \\
\text { Intensity }\end{array}$ & $\begin{array}{l}1.628 \\
(.430)\end{array}$ & $\begin{array}{l}1.390 \\
(.428)\end{array}$ & $\begin{array}{l}1.251 \\
(.662)\end{array}$ & $\begin{array}{l}-.212 \\
(.284)\end{array}$ & $\begin{array}{l}-.356 \\
(.281)\end{array}$ & $\begin{array}{l}-.942 \\
(.717)\end{array}$ \\
\hline Worker Turnover & \begin{tabular}{ll|}
-.632 \\
$(.206)$ \\
\end{tabular} & $\begin{array}{l}-.683 \\
(.207) \\
\end{array}$ & $\begin{array}{l}-.430 \\
(.332) \\
\end{array}$ & $\begin{array}{c}.132 \\
(.143)\end{array}$ & $\begin{array}{l}.070 \\
(.145)\end{array}$ & $\begin{array}{c}.163 \\
(.202)\end{array}$ \\
\hline \multicolumn{7}{|c|}{ Occupations: Base group is manual workers } \\
\hline Managers & & $\begin{array}{c}.487 \\
(.123)\end{array}$ & $\begin{array}{c}.282 \\
(.131)\end{array}$ & & $\begin{array}{l}.324 \\
(.084)\end{array}$ & $\begin{array}{l}.195 \\
(.099)\end{array}$ \\
\hline Clerical & & $\begin{array}{c}.366 \\
(.174)\end{array}$ & $\begin{array}{l}-.076 \\
(.190)\end{array}$ & & $\begin{array}{l}.161 \\
(.121)\end{array}$ & $\begin{array}{l}-.126 \\
(.121)\end{array}$ \\
\hline Personal/security & & $\begin{array}{l}.049 \\
(.355)\end{array}$ & $\begin{array}{l}.522 \\
(.371)\end{array}$ & & $\begin{array}{c}.504 \\
(.250)\end{array}$ & $\begin{array}{c}.204 \\
(.223)\end{array}$ \\
\hline Sales people & & $\begin{array}{c}.443 \\
(.276) \\
\end{array}$ & $\begin{array}{l}-.078 \\
(.281) \\
\end{array}$ & & $\begin{array}{l}-.037 \\
(.191) \\
\end{array}$ & $\begin{array}{l}-.328 \\
(.190)\end{array}$ \\
\hline No Qualifications & $\begin{array}{l}-.251 \\
(.096) \\
\end{array}$ & $\begin{array}{l}-.036 \\
(.109) \\
\end{array}$ & $\begin{array}{l}.107 \\
(.096)\end{array}$ & $\begin{array}{l}.145 \\
(.065)\end{array}$ & $\begin{array}{l}-.033 \\
(.075)\end{array}$ & $\begin{array}{c}.101 \\
(.069)\end{array}$ \\
\hline \multicolumn{7}{|c|}{ Experience: Base Group is Age $35-45$} \\
\hline Age 16-24 & $\begin{array}{l}. .579 \\
(.170) \\
\end{array}$ & $\begin{array}{l}-.461 \\
(.172) \\
\end{array}$ & $\begin{array}{l}-.390 \\
(.175) \\
\end{array}$ & $\begin{array}{l}-.315 \\
(.118) \\
\end{array}$ & $\begin{array}{l}-.259 \\
(.121) \\
\end{array}$ & $\begin{array}{l}-.153 \\
(.119) \\
\end{array}$ \\
\hline Age 25-34 & $\begin{array}{l}-.341 \\
(.155)\end{array}$ & $\begin{array}{l}-.282 \\
(.158)\end{array}$ & $\begin{array}{l}-.314 \\
(.171)\end{array}$ & $\begin{array}{l}-.198 \\
(.109)\end{array}$ & $\begin{array}{l}-.155 \\
(.110)\end{array}$ & $\begin{array}{l}-.196 \\
(.111)\end{array}$ \\
\hline Age 45-54 & $\begin{array}{l}-.058 \\
(.158)\end{array}$ & $\begin{array}{l}-.042 \\
(.156)\end{array}$ & $\begin{array}{l}-.104 \\
(.160)\end{array}$ & $\begin{array}{l}-.139 \\
(.110)\end{array}$ & $\begin{array}{l}-.148 \\
(.111)\end{array}$ & $\begin{array}{l}-.150 \\
(.101)\end{array}$ \\
\hline Age 55-64 & $\begin{array}{l}.178 \\
(.190) \\
\end{array}$ & $\begin{array}{l}.244 \\
(.192) \\
\end{array}$ & $\begin{array}{c}.142 \\
(.237) \\
\end{array}$ & $\begin{array}{l}.263 \\
(.133) \\
\end{array}$ & $\begin{array}{l}.263 \\
(.136) \\
\end{array}$ & $\begin{array}{l}.271 \\
(.138)\end{array}$ \\
\hline Male & $\begin{array}{l}.037 \\
(.097) \\
\end{array}$ & $\begin{array}{l}.114 \\
(.099) \\
\end{array}$ & $\begin{array}{l}-.116 \\
(.128) \\
\end{array}$ & $\begin{array}{c}.293 \\
(.064) \\
\end{array}$ & $\begin{array}{c}.364 \\
(.065) \\
\end{array}$ & $\begin{array}{l}-.112 \\
(.078) \\
\end{array}$ \\
\hline Small Firm & $\begin{array}{c}.068 \\
(.112) \\
\end{array}$ & $\begin{array}{l}.016 \\
(.113) \\
\end{array}$ & $\begin{array}{c}.005 \\
(.127) \\
\end{array}$ & $\begin{array}{l}-.118 \\
(.076)\end{array}$ & $\begin{array}{l}-.126 \\
(.076) \\
\end{array}$ & $\begin{array}{l}-.056 \\
(.074) \\
\end{array}$ \\
\hline Observations & 968 & 968 & 968 & 968 & 968 & 968 \\
\hline Estimation Period & 1984-1996 & 1984-1996 & 1984-1996 & 1984-1996 & 1984-1996 & 1984-1996 \\
\hline
\end{tabular}

Notes:

Standard errors (robust to heteroskedacity) in parentheses under coefficients. Bold typeface indicates that the variable is significant at the 5\% level. Variables that are significant at the 5\% level are in bold. All regressions include a full set of regional dummies (10), time dummies (12) and tenure dummies (6); observations are weighted by number of individuals in an LFS industry cell. Random effects are estimated by GLS. Within groups estimated by least squares dummy variables ( 85 industries). 
In column (1) we present the production function and in column (2) we present the wage equation. The GMM estimates tell a similar story to the within groups estimates. Training has a positive and significant impact on both productivity and wages, although the training coefficient in the production function remains almost twice the size of the coefficient in the wage equation (0.60 vs. 0.35 ). There are some minor changes to the other coefficients - the coefficient on capital intensity has risen to 0.33 in the production function, the R\&D coefficient is positively signed in the wage equation and the coefficient on hours is somewhat larger in magnitude than in Table 1.

The diagnostics reported at the base of the table are also satisfactory - there is no sign of second order serial correlation (in the first differences residuals) and the Sargan test of over-identifying restrictions does not reject. Note that the wage regression uses instruments dated $\mathrm{t}-3$ and before in the differenced equation (and dated $\mathrm{t}-2$ in the levels equation). This is because there were some signs of significant second-order serial correlation using t-2 dated instruments in the wage equation which invalidates the IVs (we dropped one period in order to be able use the longer lags in estimation). Using the (invalid) instruments on the longer time period gave a coefficient (standard error) on training of $0.141(0.067)$ in the wage equation ${ }^{28}$.

\footnotetext{
${ }^{28}$ Using the shorter time period with longer dated instruments in the production function gave a coefficient (standard error) on training of 1.043(.325). See Table B2 in the Appendix for full details.
} 
Table 2 Production Functions and Wage Equations estimated by GMM

\begin{tabular}{|c|c|c|}
\hline & (1) & (2) \\
\hline & $\ln ($ real value added per worker) & Ln(Wages) \\
\hline Training & $\begin{array}{c}.602 \\
(.181)\end{array}$ & $\begin{array}{c}.351 \\
(.106)\end{array}$ \\
\hline $\log$ (capital/worker) & $\begin{array}{c}.327 \\
(.016)\end{array}$ & $\begin{array}{l}.106 \\
(.011)\end{array}$ \\
\hline $\log$ (hours/worker) & $\begin{array}{c}.498 \\
(.064)\end{array}$ & $\begin{array}{c}.489 \\
(.027)\end{array}$ \\
\hline $\begin{array}{l}\text { Lagged R\&D } \\
\text { Intensity }\end{array}$ & $\begin{array}{l}1.905 \\
(.262)\end{array}$ & $\begin{array}{l}.443 \\
(.271)\end{array}$ \\
\hline $\begin{array}{l}\text { Proportion employees who are } \\
\text { professionals or managers }\end{array}$ & $\begin{array}{l}.306 \\
(.068) \\
\end{array}$ & $\begin{array}{l}.160 \\
(.034)\end{array}$ \\
\hline $\begin{array}{l}\text { Autocorrelation coefficient } \\
(\rho)\end{array}$ & $\begin{array}{c}.741 \\
(.014) \\
\end{array}$ & $\begin{array}{l}.797 \\
(.013)\end{array}$ \\
\hline $\begin{array}{l}\text { LM1(d.f.) } \\
\text { [p-value] }\end{array}$ & $\begin{array}{l}-4.892(85) \\
{[0.00]}\end{array}$ & $\begin{array}{l}-6.053(85) \\
{[0.00]}\end{array}$ \\
\hline $\begin{array}{l}\text { LM2(d.f.) } \\
\text { [p-value] }\end{array}$ & $\begin{array}{l}-.940(85) \\
{[.347]}\end{array}$ & $\begin{array}{l}-1.44(85) \\
{[.158]}\end{array}$ \\
\hline Sargan(d.f.) & $8.819(121)$ & $11.83(136)$ \\
\hline Instruments & $\begin{array}{l}(\mathrm{TRAIN})_{\mathrm{t}-2, \mathrm{t}-3,} \operatorname{Ln}(\mathrm{Q} / \mathrm{N})_{\mathrm{t}-2, \mathrm{t}-\mathrm{t},}, \\
\ln (\mathrm{Hrs} / \mathrm{N})_{\mathrm{t}-2, \mathrm{t}-3} \ln (\mathrm{K} / \mathrm{N})_{\mathrm{t}-2, \mathrm{t}-\mathrm{3}} \text { in } \\
\text { differenced equations; } \Delta(\mathrm{TRAIN})_{\mathrm{t}-1,}, \\
\Delta \ln (\mathrm{Hrs} / \mathrm{N})_{\mathrm{t}-1} \Delta \ln (\mathrm{K} / \mathrm{N})_{\mathrm{t}-1} \text { in the levels } \\
\text { equations. }\end{array}$ & 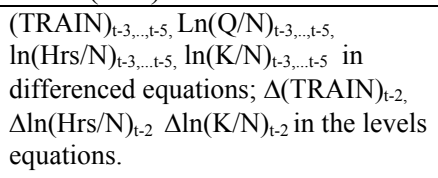 \\
\hline Estimation Period & 1984-1996 & $1985-1996$ \\
\hline Observations & 898 & 883 \\
\hline
\end{tabular}

\section{Notes:}

Estimation by GMM-SYS in Arellano and Bond (1998) DPD-98 package written in GAUSS, one step robust estimates reported; all regressions include the current values of all the variables in Table 1 columns (3) and (6) (i.e. turnover, other occupations, qualifications, age, tenure, gender, region, firm size and time dummies). Capital intensity, training, hours and lagged productivity are always treated as endogenous. The other variables are assumed weakly exogenous. One step standard errors (robust to arbitrary heteroskedacity and autocorrelation of unknown form) in parentheses under coefficients (variables significant at 5\% level are in bold); LM1(2) is a Lagrange Multiplier test of first (second) order serial correlation distributed N[1,0] under the null (see Arellano and Bond, 1991); Sargan is a Chi-squared test of the over-identifying restrictions; observations weighted by number of individuals in an LFS industry cell. Full details in Table B2. 
Table 3 Robustness Tests of the Production Function

\begin{tabular}{|c|c|c|c|}
\hline Row & Robustness test & NT & $\begin{array}{r}\text { Training coefficient } \\
\text { (standard error) }\end{array}$ \\
\hline 1 & $\begin{array}{l}\text { Original training coefficient in production sector, Table } 1 \\
\text { column (3) }\end{array}$ & 968 & $0.696(0.201$ \\
\hline 2 & Using "stock" of trained workers instead of flows & 968 & $0.775(.189)$ \\
\hline 3 & $\begin{array}{l}\text { Using the balanced panel only to check for bias associated with } \\
\text { finite T (Nickell, 1981) }\end{array}$ & 572 & $0.508(0.289)$ \\
\hline 4 & $\begin{array}{l}\text { Conditioning on wage in productivity regression (to control for } \\
\text { any residual unobserved worker quality) }\end{array}$ & 968 & $\begin{array}{r}\text { Training: } \\
\text { 0.659(0.219) } \\
\text { Wage coeff.: } \\
0.099(0.130)\end{array}$ \\
\hline 5 & Including service sectors & 1059 & $0.727(0.206)$ \\
\hline 6 & Include union density (only available 1989-96) & 547 & $\begin{array}{r}\text { Training: } \\
\mathbf{0 . 6 0 3 ( 0 . 2 6 6 )} \\
\text { union: } \\
-0.177(0.183)\end{array}$ \\
\hline 7 & Allow all industries to have different training coefficients & 968 & $\begin{array}{r}\text { mean of } \\
\text { heterogeneous } \\
\text { coefficients: } 0.510\end{array}$ \\
\hline 8 & Allow non-constant returns & 968 & 0.725(.201) \\
\hline 9 & Estimating a translog production function & 968 & $0.703(.201)$ \\
\hline 10 & Estimation by non-linear least squares & 968 & 0.518(.197) \\
\hline 11 & Estimation on 1993-2001 data (region-industry cells) & 1873 & $0.436(.188)$ \\
\hline
\end{tabular}

\section{Notes}

These all use the specification in the third column of Table 1 (unless otherwise specified). Estimation by within groups, robust standard errors in parentheses.

\subsection{Robustness of the Results}

We conducted a large number of robustness tests on the models in these tables. Table 3 reports some of these. Given the similarity of the within groups and GMM results we performed these tests on the within groups specifications of table 1 (column (3)). The first row of Table 3 simply reports the coefficient and standard error from this table. Using the stock of trained employees instead of the flow (calculated allowing for depreciation due to inter-firm turnover) results in very similar results in row $2^{29}$. Keeping only industries

\footnotetext{
${ }^{29}$ The non-fixed effects results were significantly different, but the deviations around the fixed effect in the training stock are dominated by the flow, explaining the similarity of the results. In addition to using the empirical turnover rates we assumed an exogenous depreciation of training at $40 \%$ per annum (see Data Appendix). The coefficient was stable to reasonable changes in these parameters (e.g. increasing the depreciation rate to $50 \%$ p.a. increased the coefficient to 0.81 , to $60 \%$ to 0.82 . Decreasing the depreciation rate to $30 \%$ reduced the coefficient to 0.70 ).
} 
which had fourteen continuous years of data (balanced panel) in row 3 means losing $40 \%$ of the observations; the coefficient falls, but the change is not significant. The fourth row includes average wages on the right hand side of the production function as a measure of unobserved worker quality. Although wages have a positive and significant coefficient, the training association remains robust. In row 5 we include all the service sectors, ignoring our concerns over data quality. The coefficient on training rises to 0.73 and remains significant (although the standard error is higher).

Since training is correlated with unionisation, we could be picking up "collective voice" effects in the main results. Union membership is only available in LFS since 1989. Despite the loss in sample in row 6, the training effect is robust to inclusion of union density (density is insignificantly negatively associated with productivity). In row 7 we allow the training effect to be different in each of the 85 industries. The mean of these heterogeneous coefficients is close to the pooled results. The next two rows allow for more general functional forms relaxing first constant returns (row 8) and then estimating a translog production function (row 9). In both cases the training coefficient is essentially unchanged. Row 10 gives the results from a nonlinear least squares estimation (equation 8 in section 2) again showing no significant difference.

We also compared our results with a recent paper (Machin et al, 2003) that has built up similar data to our own covering a more recent period and exploiting the larger size of the LFS post 1992 to construct industry by region cells. Against these advantages their dataset has a shorter time series component (1993-2001) and lacks some of the covariates we use. Reestimating identical specifications on their dataset gives an estimate of the training association with productivity of 0.436 with a standard error of 0.188 (see row 11 of Table 3). This is lower, but is still significant and remains well within two standard errors of our main results. ${ }^{30}$ On our dataset we tested

\footnotetext{
${ }^{30}$ The specification is identical to table 1 column (3) except we drop the occupational proportions and R\&D and include employment. On our data this gives a coefficient (standard error) on TRAIN of $.732(.205)$.
} 
whether there was a tendency for the training coefficient to fall (or rise) over time in the production function, but we found it to be stable ${ }^{31}$.

Does the "wedge" between the wage and productivity effect of training arise from specific human capital or imperfect competition? Under most forms of imperfect competition, we conjectured that the wedge would be larger in those industries where workers were earning less than would be implied by their human capital (i.e. inter-industry wage premia were low). This could be because the "low paying" industries were monopsonistic with large search frictions or because workers are more able to capture the quasi-rents from training in the "high paying" industries.

In order to identify such industries we used estimates of inter-industry wage premia taken from the US Current Population Survey ${ }^{32}$. We matched the US industries to the UK industries and split the sample at the median sectoral wage premia. Allowing an interaction between training and this industry split revealed that the wedge between the training effect on productivity and the training effect on wages was solely within the "low wage" industries. To be precise, including an interaction in the wage equation between training and low wage industries gave a coefficient (standard error) of $-0.664(0.196)$ on the interaction and $0.531(0.113)$ on the linear training effect. In the production function the interaction was $0.332(0.297)$ - positive but insignificant. In other words, in the "high wage premium" industries there was no significant difference between the impact of training on productivity and the impact of productivity on wages. The fact that our results are driven by the wedge in low paying sectors is tentative evidence in favour of a monopsony/search interpretation.

\footnotetext{
${ }^{31}$ For example interacting TRAIN with a trend in the production function gave a coefficient of .003 with a standard error of .044.

${ }^{32}$ Estimating inter industry wage premia from UK wages would have been more problematic as these could reflect endogenous influences - US wage setting will be driven by the structural characteristics of the industries in question. These US wage inter industry wage premia were generated from individual level wage regressions from the 1986 CPS Merged Outgoing rotation files. The wage regressions included years of schooling, a quartic in experience, gender, marital status,
} 
This evidence is open to the critique that firm specific training may be systematically more prevalent in the low wage sectors (although a priori the usual view is that "good jobs" are more likely to have more specific skills). There are several questions in LFS that could be interpreted as general vs. specific training, so we used them to see if the coefficients differed significantly with training type - they did not. For example there are questions related to off the job training (more general) and on-the-job training (more specific). The proportion of off the job training produced a coefficient (standard error) of $0.005(0.018)$ when added to the wage regression and a coefficient (standard error) $0.018(0.029)$ when added to the production function. We view this not as any rejection of specific human capital theory per se, but rather because the type of human capital is intrinsically difficult to measure. Furthermore, the LFS questions are not asked in all years and have many missing values.

\subsection{Quantifying the effects of Training}

Our key qualitative conclusions are first, that there is a significant impact of training on productivity and second, that the effects of training on productivity are larger than the effects of training on wages. But quantitatively, how economically significant is the magnitude of the training effect?

Interpreting the magnitude of the coefficients is difficult, but the implied effects are large. From Tables 1 and 2 we conservatively take the coefficient on training in the productivity regressions to be about 0.6 and the coefficient on training in the wage regressions to be about 0.3 . This would imply a 10 percentage point increase in the training measure is associated with a $6 \%$ increase in productivity and a $3 \%$ increase in wages.

Relative to the returns to schooling literature the training impacts appear high $^{33}$ (although Dearden et al, 2000, show that our estimates of the training effects on wages are actually quite low compared to existing UK estimates 
such as Booth, 1993, and Blundell et al, 1996). Card (1999) puts the impact of a year of schooling on wages at about $10 \%$, so our baseline impact of 0.3 is about three times as large. Given that the typical time in training during the four week period is under a month (the median is two weeks, the average is higher), the returns to a month of training appear even more impressive. For example an increase in our key variable, TRAIN, of $10 \%$ would imply a typical worker only spent $5 \%$ extra of his time in training if training spells were on average 2 weeks long.

Of course, there may be remaining econometric problems we have still not controlled for generating this difference. But assuming the training effect is not a statistical artifact there remain at least two possible explanations for the larger size of the training coefficients compared to conventional estimates of the return to schooling. First, work-related training may have a higher private return than schooling as training is more directed at raising productivity in employment. Training is also likely to have a faster rate of depreciation than schooling, so it requires a higher year on year return in order to give incentives for investment ${ }^{34}$. Secondly, there may be externalities associated with training that are missed in the conventional schooling literature which focuses on private returns whereas we look at returns to the industry as a whole (cf. Moretti, 2004).

To investigate the externality issue we estimated some individual level wage regressions on the LFS panel. If the private returns to training are higher than the social returns we might expect to see a similarly high coefficient in the individual level wage regression. We used the individual level equivalents of the variables in the industry level regressions. To construct the proportion of the year spent in training we used the LFS panel which follows individuals for 5 quarters and asks individuals the training question in each quarter. We defined a dummy variable (TRAIND4) indicating whether the individual had

\footnotetext{
${ }^{33}$ Compared to existing UK estimates of the training effects on wages (e.g. Booth, 1993 and Blundell et al, 1996) our estimates are actually lower (see Dearden et al, 2000, for a detailed comparison).

34 See Heckman et al (2003) for a recent discussion of interpretation of the schooling coefficient in wage regressions.
} 
been involved in some training in all of the previous four quarters. We also defined dummies for if the individual had been in training for 3 quarters (TRAIND3), 2 quarters (TRAIND2), one quarter (TRAIND1) or not at all (TRAINDO). Using TRAINDO as the omitted base the results we obtained from a typical regression were ${ }^{35}$ :

$\ln ($ wage $)=.165(.033) T R A I N D 4+.092(.023) T R A I N D 3+.125(.019) T R A I N D 2$

$+.078(.015)$ TRAIND1 + controls

Longer lengths of time in training are associated with significantly higher wages $^{36}$. The coefficient on receiving training in all four quarters is 0.165 ; this is comparable with the industry level coefficient of 0.350 . Taken literally this would suggest that about half of the impact of training on wages at the industry level is attributable to externalities.

If we include a set of industry dummies (which will include potential spillovers) the coefficient on TRAIND4 falls from 0.16 to 0.13 . If we also include the initial wage in the first quarter (to control for unobserved heterogeneity) then the coefficient falls even further to 0.079. So these impacts of a "year" of training are rather similar to the conventional impacts of the returns to a year in school.

Our conclusion from this exercise is that the larger magnitude of the training effects in this paper primarily reflects our strategy of estimating at a level above the individual worker. This was forced upon us by the absence of adequate data on firm productivity and training, but also because of our desire to incorporate externalities. The results are therefore consistent with a story which stresses externalities to training.

\footnotetext{
${ }^{35}$ Estimation was by OLS with robust standard errors are in parentheses. Controls include gender, age, areas (20), employer size, occupational dummies (8), no qualification dummy, and a dummy for parttime status. Results are for the production sector only. The quarterly LFS panel 1997-1998 was used as two wage observations per individual did not exist in the LFS prior to this. There were 3998 observations and full results available on request from the authors.
} 
Even if there remain econometric problems that have caused us to have overestimated the impact of training at the industry level, it is hard to see why this would not also bias upwards the training coefficient in the production function and wage equations to a similar extent. Therefore, even if one disputes the exact quantitative magnitude of the training effect, our key qualitative conclusion that the productivity impact of training is much greater than the wage impact should still be valid (that is also a feature of the firm level results in Appendix B).

\section{Conclusions}

In this paper we have examined the issue of the impact of private sector training on productivity. Rather than simply use wages as a measure of productivity we present (for the first time) estimates of the impact of training on productivity over a long time period. We have assembled a data set which aggregates individual level data on training and establishment data on productivity and investment into an industry panel covering 1983-1996. We control for unobserved heterogeneity and the potential endogeneity of training using a variety of methods including GMM system estimation.

Using this new data, we identify a statistically and economically significant effect of training on value added per head in the UK. An increase of one percentage point in the proportion of employees trained is associated with about a $0.6 \%$ percent increase in productivity and a $0.3 \%$ increase in wages.

We argued that the methodologies in the existing literature may underestimate the importance of training. The focus on wages as the only relevant measure of productivity ignores the additional productivity benefits the firm may capture. Throughout our results we found that the overall effect of training on productivity was around twice as large as the effects on wages (even using firm level data). This result could occur even under standard specific human capital theory. But it could also arise for a number of other reasons due to

\footnotetext{
${ }^{36}$ The training effects are not monotonic. There is even a perverse fall in the coefficient on being in training 3 relative to 2 quarters, although the coefficients are not significantly different.
} 
imperfect competition in the labour market (and we present some evidence consistent with this hypothesis). Clearly further research is needed to distinguish between these different theories.

Finally, a comparison between the industry and individual level wage regressions suggests that our industry level analysis may capture externalities from training that are missed out in the micro-level studies. An important avenue of future research would include probing the returns to training by combining enterprise data with industry-level data to investigate the externalities story in greater detail. 


\section{A. Data Appendix}

\section{A.1 Data construction for industry panel}

The database we construct combines several sources. The critical individual level source is UK Labour Force Survey (LFS) which covered. LFS is a largescale household interview based survey of individuals in the UK which has been carried out on varying bases since $1975^{37}$. Around 60,000 households have been interviewed per survey since 1984. The LFS data are useful for our purposes as they contain detailed information on:

- the extent and types of training undertaken by employees in the survey;

- personal characteristics of interviewees (e.g. age, sex, region);

- the skills of individuals (educational qualifications and occupation);

- some basic workplace characteristics (e.g. employer size, industry);

- job characteristics of employees (e.g. job tenure, hours of work).

We work with this information aggregated into proportions and/or averages by (broadly) three digit SIC80 industry. Our sample includes all employed men and women aged between 16 and 64 inclusive (i.e. employees plus the selfemployed) for whom there was information on the industry under which their employment was classified.

The main training question asked to employees in the Labour Force Survey between 1983 and 1996 was, "over the 4 weeks ending Sunday ... have you taken part in any education or training connected with your job, or a job that you might be able to do in the future ... ?" Figure A.1 below shows the average proportions of employees undertaking training in each year of the LFS sample. It shows a reasonably steady increase in the proportion of employees in the LFS receiving training in the $1980 \mathrm{~s}^{38}$. From 1990 onwards, the proportion of employees receiving training stabilises at around $14 \%$ and stays at or around this level for the rest of the sample period.

We did some simple decomposition analyses to investigate whether the increase in aggregate training was due to the growth in size of industries which are (and always have been) relatively more training intensive. It turns out that this is only a minor factor: over $95 \%$ of the increase in aggregate training is due to an increase within a large number of different sectors ${ }^{39}$. This

\footnotetext{
${ }^{37}$ Between 1975 and 1983 the survey was conducted every two years; from 1984 until 1991 it was conducted annually. Since 1992 the Labour Force survey has been conducted every three months in a five-quarter rolling panel format.

${ }^{38}$ It should be noted that the figure of around 5\% for 1983 is almost certainly an underestimate because in 1983 the 4 week training question was only asked of employees under 50, whereas in all subsequent years it was asked of employees over 50 and under 65 as well. However, even if the training measure is calculated as the proportion of employees aged under 50 receiving training in every year, the figure for 1983 is still lower than for 1984.

${ }^{39}$ The change of training propensity over a given period. can be decomposed into a within-industry and a between-industry component: $\Delta T=\sum_{i} \Delta S_{i} \bar{T}_{i}+\sum_{i} \Delta T_{i} \bar{S}_{i}$ where $T=$ proportion of workers undertaking training, $S=$ share of industry $i$ in total employment, a bar denotes a mean over time and the delta is the difference over the same two time periods.
} 
is consistent with the findings of other papers which have found that the aggregate growth of education or occupational skills is essentially a within industry phenomenon (e.g. Machin and Van Reenen, 1998).

Figure A.1. Overall Training Incidence, Labour Force Survey, 1983-96

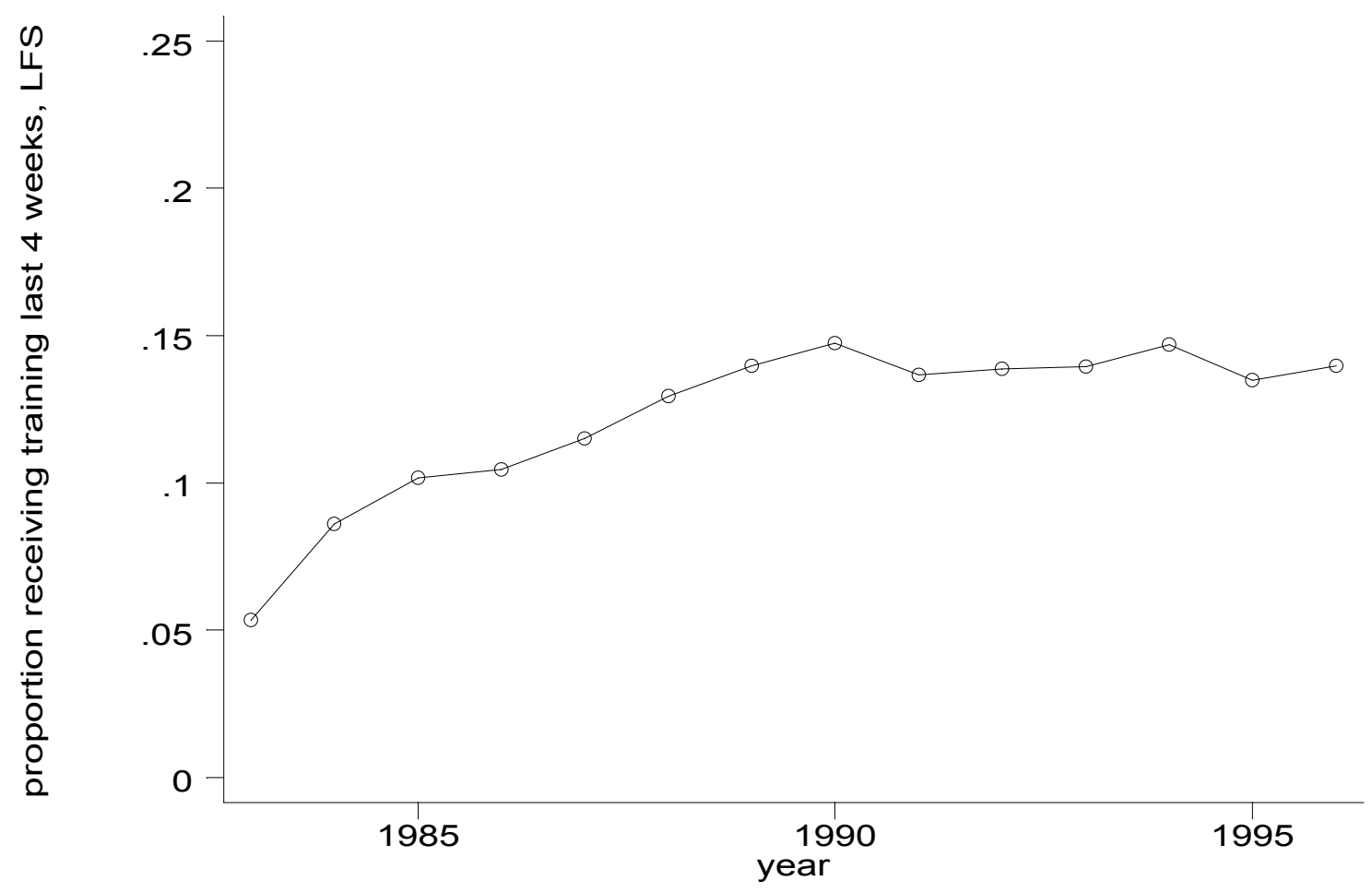

LFS also has further information on the type of training received (although not all of these are asked in each year). For example, the questionnaire distinguishes between "on-the-job" training (e.g. learning by example and practice while doing the job) and "off-the-job" training (training conducted as a formal training course). Whilst the incidence of on-the-job training reported in the LFS has been more or less constant since the mid-1980s, the proportion of workers receiving some off-the-job training in the 4 weeks prior to being surveyed rose from about $5 \%$ in 1984 to $8 \%$ in the early 1990s. Other indicators of training (not asked in every year) include the duration of training, whether it was employer funded, whether it was completed or still ongoing. We examined whether there were differential productivity effects for all these different types of training, but could find no significantly different coefficients ${ }^{40}$.

\footnotetext{
${ }^{40}$ The measure or training used takes no account of the intensity or length of the training course (except insofar as a longer training course is more likely to fall within the 4-week period prior to the survey). There is some evidence that the length of training has been falling since the later 1980s (for a detailed analysis see Felstead et. al. (1997)). However, when we estimate training effects separately for each year of the LFS sample, the magnitude of the training effect does not differ significantly over time. One might expect a decrease in the productivity effect of the training measure for the later years if the average quality of training courses has declined (there was no evidence of this in our data).
} 
The second major dataset we use is the Annual Census of Production (ACOP). This gives production statistics on capital, labour and output for industries in the manufacturing, energy and water sectors (collectively known as the production sector of the economy). It is based on the ARD (Annual Respondents Database) which is a survey of all production establishments (plants) in the UK with 100 or more employees, plus a subset of establishments with less than 100 employees. We use the COP data on value added, gross output, investment, employment and wages for industries in the manufacturing sector and the energy and water industries.

Capital stocks were calculated using the perpetual inventory method drawing on NIESR's estimates on initial capital stocks (see O'Mahony and Oulton, 1990). All the nominal measures were deflated with three digit industry price indices from ONS. For the services industries we drew on the ISDB (InterSectoral DataBase) compiled by the OECD.

There was a change in SIC classification in 1992 which forced us to aggregate some of the industries and prevented us from using some of the industries after the change. Additionally, we insisted on having at least 25 individuals in each cell in each year. After matching the aggregated individual data from LFS we were left with 94 industry groupings over (a maximum of) 14 years $^{41}$ (85 in the production sectors)

Means of the variables are given in Table A1 broken down by high and low training sectors.

\section{A.2 Calculating the Training Stock}

The main results use the flow in training, but we also report some experiments with an estimate of the stock of trained workers in an industry. If we define the stock of people who have been trained in the industry at time $t$ as $N^{T}$ and the flow as $M^{T}$ then if the stock evolves according to the standard perpetual inventory formula it can be expressed as:

$$
N_{t}^{\top}=M_{t}^{\top}+(1-\delta) N_{t-1}^{\top}
$$

where $\delta$ is the rate at which the stock of effectively trained workers at time $t$ decay in their productive usefulness by $\mathrm{t}+1$. This training depreciation rate represents several things. First, individuals will move away from the industry, so their training can no longer contribute to the industry's human capital stock. Second, the usefulness of training will decline over time as old knowledge becomes obsolete and people forget (e.g. knowledge of the DOS operating system). Third to the extent that training is firm-specific, turnover between firms in the same industry may reduce industry productivity. Although we obtain some measures of turnover using the LFS, the second element of depreciation is essentially unknown. Because of this uncertainty our baseline results simply use the proportion of workers trained in an industry (TRAIN in

\footnotetext{
${ }^{41}$ Full details on how the data was set can be obtained from the authors or in Dearden, Reed and Van Reenen (2000).
} 
equation (3)). This will be equal to the stock when $\delta=1$. Nevertheless, we also estimate the training stock. We used the average worker turnover rate as one element of depreciation and then added an extra "exogenous element" varying between 0.2 and 0.6 . We also need to make an assumption over the initial stock in 1983. We assume that the steady state growth $(g)$ rate of the training stock is $2 \%$ per annum which enables a first year approximation of the stock as $\mathrm{M}^{\top}{ }_{83} /(\mathrm{g}+\delta)$. The qualitative results are quite robust over different measures ${ }^{42}$.

\section{A.3 Firm Level Data}

The firm level data is based on the "Survey on Human Resource Practices and Corporate Value in the Modern Corporation" conducted in 1996 by Martin Conyon (See Conyon and Reed, 1999). The relevant training variable was q23f "How have the following training strategies used by your company changed between 1990 and 1995...The percentage of company sales turnover spent on training has increased/decreased/not changed". 135 firms gave some response to this question. We matched this survey to company accounting data from Datastream (data between 1968 and 1997). We discarded firms with missing values on the training and accounting variables leaving us with a sample of 119 companies.

Productivity was measured by real sales (Datastream Item 104) per worker (Item 219). Capital is the historical book value (Item 330) and wages were estimated as total remuneration (Item 215) divided by the number of workers (Item 219). All accounts are consolidated.

\footnotetext{
${ }^{42}$ See the discussion around Table 3 Row 2 in the main text. We also considered looking at the inflows of trained workers from other industries to improve the stock measure, but the LFS sample of industry switchers was too small to construct the full three digit flow matrix.
} 
Table A1

Means of Variables by High and Low Training Industries

\begin{tabular}{|c|c|c|}
\hline Variable & $\begin{array}{r}\text { Mean (low training } \\
\text { industries) }\end{array}$ & $\begin{array}{r}\text { Mean (high training } \\
\text { industries) }\end{array}$ \\
\hline proportion of male employees & $62.4 \%$ & $80.9 \%$ \\
\hline proportion aged: $16-24$ & $22.7 \%$ & $15.5 \%$ \\
\hline$: 25-34$ & $24.5 \%$ & $25.4 \%$ \\
\hline : 35-44 & $22.2 \%$ & $24.0 \%$ \\
\hline$: 45-54$ & $19.1 \%$ & $22.1 \%$ \\
\hline$: 55-64$ & $11.1 \%$ & $12.8 \%$ \\
\hline \multicolumn{3}{|l|}{ proportion in occupation: } \\
\hline :professional/managerial & $14.7 \%$ & $27.1 \%$ \\
\hline :clerical & $8.5 \%$ & $10.9 \%$ \\
\hline :personal/security & $1.9 \%$ & $1.6 \%$ \\
\hline :salesforce/technical & $3.4 \%$ & $2.5 \%$ \\
\hline :other occupations & $71.5 \%$ & $58.0 \%$ \\
\hline \multicolumn{3}{|l|}{ highest qualification: } \\
\hline :degree & $2.6 \%$ & $7.3 \%$ \\
\hline :sub-degree level & $3.7 \%$ & $9.2 \%$ \\
\hline :A level / equivalent & $15.5 \%$ & $22.5 \%$ \\
\hline :O level/ equivalent & $15.6 \%$ & $14.3 \%$ \\
\hline :other/none/missing & $62.7 \%$ & $46.7 \%$ \\
\hline \multicolumn{3}{|l|}{ tenure in current job: } \\
\hline :less than 6 months & $10.9 \%$ & $7.1 \%$ \\
\hline :6 months - 1 year & $8.4 \%$ & $5.8 \%$ \\
\hline$: 1$ year -2 years & $11.1 \%$ & $8.0 \%$ \\
\hline$: 2$ years -5 years & $21.6 \%$ & $17.8 \%$ \\
\hline$: 5$ years -10 years & $18.8 \%$ & $19.7 \%$ \\
\hline$: 10$ years -20 years & $18.0 \%$ & $24.3 \%$ \\
\hline :more than 20 years & $9.0 \%$ & $16.5 \%$ \\
\hline proportion in small firm & $21.2 \%$ & $12.6 \%$ \\
\hline average log capital-labour ratio & 2.22 & 3.02 \\
\hline $\begin{array}{l}\text { average log real value added per } \\
\text { worker }\end{array}$ & 2.76 & 3.19 \\
\hline average log gross output per worker & 3.80 & 4.27 \\
\hline average log hourly wages & 1.56 & 1.84 \\
\hline average hours worked & 39.1 & 40.2 \\
\hline $\begin{array}{l}\text { average R\&D spend as proportion of } \\
\text { output }\end{array}$ & 0.52 & 2.99 \\
\hline
\end{tabular}

\section{Notes}

'High Training' industries are those that trained on average more than $8.7 \%$ of employees (the sample median). 


\section{Appendix B - additional Results}

\section{B1. Some firm level results}

As a preliminary investigation of the impact of training on productivity we turned to the only UK dataset we know of that combines training data and objective productivity measures at the firm level. We constructed this by combining a firm survey with company accounting data from Datastream (see Data Appendix for details). We estimated an OLS production function in long differences (1995-1990) with results summarized in Table B1. The drawback of the firm level training data is we only know whether a firm increased the percentage of turnover allocated to training over this time period and not the actual quantitative change, so the table is simply illustrative.

The first and second columns of Table B1 give results for productivity and the third and fourth columns have the results for wages. The second and fourth columns condition on industry dummies. In columns (1) and (3) the indicator for the change in training is positively and significantly associated with both productivity changes and with wage changes. Interestingly, the magnitude of the association with productivity is about twice as large as the magnitude of the association with wages. We uncovered a similar finding when we examined the industry level data ${ }^{43}$. A second feature of Table B1 is that much of the association between training, productivity and wages is due to industry level (growth) effects. The coefficient on training falls by half in the productivity regression when sector dummies are added (column 2 ) and by three quarters in the wage equation (column 4). The training effects are no longer significant. This implies that a substantial element of the training correlation is due to industry growth effects. It is these changes over a much longer time period that we exploited in the main part of the paper ${ }^{44}$.

\section{B2. More detailed industry results}

Table B2 reports the unrestricted coefficient estimates underlying Table 2 in the main text and the restricted estimates of the production function parameters after imposing the COMFAC restrictions. If we took the unrestricted coefficients our preferred models in columns (1) and (4) would suggest a larger magnitude of the long-run impact of training on productivity ${ }^{45}$ (2.289) of training on wages (1.215). The qualitative finding that the productivity effect is twice the size of the wage effect remains unaltered.

\footnotetext{
${ }^{43}$ Given the size of the sample, it is not surprising that the difference in training coefficients is not significant ( $p$-value $=.23$, allowing for cross equation correlation of the errors through SUR).

${ }^{44}$ In the spirit of looking for complementarities (Ichinowski et al, 1997) we investigated allowing for interactions between changes in training and changes in many other features of the firm - merit pay across four different skill groups, employee involvement, retention, flexibility, three types of delayering, share options, teamwork, competition, etc. With the exception of merit pay for managers (which was significant at the $10 \%$ level) none of these interactions were statistically significant. It is worth noting that neither Black and Lynch (1997) nor Bartel (1995) find strong evidence of such interactions in their data.

${ }^{45}$ i.e. using $\left(\pi_{2}+\pi_{3}\right) /\left(1-\pi_{1}\right)$ in the context of equation (14).
} 
Table B1: Training, Productivity and Wages at the firm level

Long-differences 1995-1990

\begin{tabular}{|c|c|c|c|c|}
\hline & (1) & (2) & (3) & (4) \\
\hline $\begin{array}{l}\text { Dependent } \\
\text { variable: }\end{array}$ & \multicolumn{2}{|c|}{ Mean change in $\ln ($ Sales per worker) } & \multicolumn{2}{|c|}{ Mean change in $\ln ($ Average Wage) } \\
\hline $\begin{array}{l}\text { Growth in } \\
\text { Training as a } \\
\text { percentage of } \\
\text { turnover }\end{array}$ & $\begin{array}{l}.021 \\
(.009)\end{array}$ & $\begin{array}{l}.010 \\
(.010)\end{array}$ & $\begin{array}{l}.012 \\
(.006)\end{array}$ & $\begin{array}{l}.003 \\
(.007)\end{array}$ \\
\hline $\begin{array}{l}\text { Mean change in } \\
\ln \text { (Capital per } \\
\text { worker) }\end{array}$ & $\begin{array}{l}.139 \\
(.045)\end{array}$ & $\begin{array}{l}.159 \\
(.049)\end{array}$ & $\begin{array}{l}.066 \\
(.032)\end{array}$ & $\begin{array}{l}.103 \\
(.033)\end{array}$ \\
\hline $\begin{array}{l}\text { Sector dummies } \\
\text { (32) }\end{array}$ & No & Yes & No & Yes \\
\hline Observations & 119 & 119 & 119 & 119 \\
\hline $\mathrm{R}^{2}$ & .41 & .62 & .22 & .63 \\
\hline
\end{tabular}

Notes

Estimation by OLS in long differences (average 1995-1990); robust standard errors under coefficients. All regressions include controls for the growth in employment and whether there was an increase in the proportion of skills (4 groups: managers, clerical, skilled manual, unskilled manual), of females, and of part timers. These are all continuous variables. "Growth in Training as a percentage of turnover" is a dummy variable indicating whether training grew as a percentage of turnover between 1990 and 1995. 
Table B2: Detailed GMM results

\begin{tabular}{|c|c|c|c|c|}
\hline & (1) & $(2)$ & (3) & (4) \\
\hline & \multicolumn{2}{|c|}{ Ln(real value added per worker) } & \multicolumn{2}{|c|}{ Ln(Wages) } \\
\hline \multicolumn{5}{|c|}{ Constrained - COMFAC Imposed } \\
\hline Training & $\begin{array}{c}.602 \\
(.181)\end{array}$ & $\begin{array}{l}1.043 \\
(.325)\end{array}$ & $\begin{array}{c}.141 \\
(.067)\end{array}$ & $\begin{array}{l}.351 \\
(.106)\end{array}$ \\
\hline $\log$ (capital/worker) & $\begin{array}{l}.327 \\
(.016)\end{array}$ & $\begin{array}{l}.325 \\
(.016)\end{array}$ & $\begin{array}{l}.188 \\
(.006)\end{array}$ & $\begin{array}{l}.106 \\
(.011)\end{array}$ \\
\hline $\log$ (hours/worker) & $\begin{array}{l}.498 \\
(.064)\end{array}$ & $\begin{array}{l}.519 \\
(.062)\end{array}$ & $\begin{array}{l}.518 \\
(.031)\end{array}$ & $\begin{array}{c}.489 \\
(.027)\end{array}$ \\
\hline $\begin{array}{l}\text { Lagged R\&D } \\
\text { Intensity }\end{array}$ & $\begin{array}{l}1.905 \\
(.262)\end{array}$ & $\begin{array}{l}1.538 \\
(.340)\end{array}$ & $\begin{array}{l}.226 \\
(.159)\end{array}$ & $\begin{array}{c}.443 \\
(.271)\end{array}$ \\
\hline $\begin{array}{l}\% \text { employees who } \\
\text { are professionals or } \\
\text { managers }\end{array}$ & $\begin{array}{l}.306 \\
(.068)\end{array}$ & $\begin{array}{c}.327 \\
(.074)\end{array}$ & $\begin{array}{c}.306 \\
(.068)\end{array}$ & $\begin{array}{l}.160 \\
(.034)\end{array}$ \\
\hline years & $1984-1996$ & $1985-1996$ & 1984-1996 & $1985-1996$ \\
\hline NT & 898 & 833 & 898 & 883 \\
\hline $\begin{array}{l}\text { Autocorrelation } \\
\text { coefficient } \\
(\rho)\end{array}$ & $\begin{array}{l}.741 \\
(.014)\end{array}$ & $\begin{array}{c}.758 \\
(.014)\end{array}$ & $\begin{array}{c}.822 \\
(.009)\end{array}$ & $\begin{array}{c}.797 \\
(.013)\end{array}$ \\
\hline $\begin{array}{l}\text { LM1 (d.f.) } \\
\text { [p-value] }\end{array}$ & $\begin{array}{l}-4.892(85) \\
{[0.00]}\end{array}$ & $\begin{array}{l}-4.513(85) \\
{[0.00]}\end{array}$ & $\begin{array}{l}-5.444(85) \\
{[0.00]}\end{array}$ & $\begin{array}{l}-6.053(85) \\
{[0.00]}\end{array}$ \\
\hline $\begin{array}{l}\text { LM2 (d.f.) } \\
\text { [p-value] }\end{array}$ & $\begin{array}{c}.-.940(85) \\
{[.347]} \\
\end{array}$ & $\begin{array}{c}-.674(85) \\
{[.500]} \\
\end{array}$ & $\begin{array}{c}-2.003 \\
{[.045]} \\
\end{array}$ & $\begin{array}{c}-1.44(85) \\
{[.158]} \\
\end{array}$ \\
\hline Sargan (d.f.) & $8.819(121)$ & $6.605(146)$ & $11.03(121)$ & $11.83(146)$ \\
\hline Instruments & $\begin{array}{l}(\text { TRAIN })_{\mathrm{t}-2, \mathrm{t}-3,} \\
\operatorname{Ln}(\mathrm{Q} / \mathrm{N})_{\mathrm{t}-2, \mathrm{t}-3}, \\
\ln (\mathrm{Hrs} / \mathrm{N})_{\mathrm{t}-2, \mathrm{t}-3} \\
\ln (\mathrm{K} / \mathrm{N})_{\mathrm{t}-2, \mathrm{t}-3} \text { in } \\
\text { differenced } \\
\text { equations; } \\
\Delta(\mathrm{TRAIN})_{\mathrm{t}-1,}, \\
\Delta \ln (\mathrm{Hrs} / \mathrm{N})_{\mathrm{t}-1} \\
\Delta \ln (\mathrm{K} / \mathrm{N})_{\mathrm{t}-1} \text { in } \\
\text { the levels } \\
\text { equations. }\end{array}$ & $\begin{array}{l}(\mathrm{TRAIN})_{\mathrm{t}-3, . . \mathrm{t}-5,} \\
\mathrm{Ln}(\mathrm{Q} / \mathrm{N})_{\mathrm{t}-3, . . \mathrm{t}-5,} \\
\ln (\mathrm{Hrs} / \mathrm{N})_{\mathrm{t}-3, \ldots \mathrm{t}-5,} \\
\ln (\mathrm{K} / \mathrm{N})_{\mathrm{t}-3, \ldots \mathrm{t}-5} \text { in } \\
\text { differenced } \\
\text { equations; } \\
\Delta(\mathrm{TRAIN})_{\mathrm{t}-2,} \\
\Delta \ln (\mathrm{Hrs} / \mathrm{N})_{\mathrm{t}-2} \\
\Delta \ln (\mathrm{K} / \mathrm{N})_{\mathrm{t}-2} \text { in the } \\
\text { levels equations. }\end{array}$ & $\begin{array}{l}\text { (same as column } \\
\quad 1)(\mathrm{TRAIN})_{\mathrm{t}-2, \mathrm{t}-3,} \\
\mathrm{Ln}(\mathrm{Q} / \mathrm{N})_{\mathrm{t}-2, \mathrm{t}-3} \\
\ln (\mathrm{Hrs} / \mathrm{N})_{\mathrm{t}-2, \mathrm{t}-3} \\
\ln (\mathrm{K} / \mathrm{N})_{\mathrm{t}-2, \mathrm{t}-3} \text { in } \\
\text { differenced } \\
\text { equations; } \\
\Delta(\mathrm{TRAIN})_{\mathrm{t}-1,}, \\
\Delta \ln (\mathrm{Hrs} / \mathrm{N})_{\mathrm{t}-1} \\
\Delta \ln (\mathrm{K} / \mathrm{N})_{\mathrm{t}-1} \text { in the } \\
\text { levels equations. }\end{array}$ & $\begin{array}{l}\text { (same as column } \\
2)(\mathrm{TRAIN})_{\mathrm{t}-3, \ldots, \mathrm{t}-5,} \\
\mathrm{Ln}(\mathrm{Q} / \mathrm{N})_{\mathrm{t}-3, . ., \mathrm{t}-5,} \\
\ln (\mathrm{Hrs} / \mathrm{N})_{\mathrm{t}-3, \ldots \mathrm{t}-5,} \\
\ln (\mathrm{K} / \mathrm{N})_{\mathrm{t}-3, \ldots . \mathrm{t}-5} \text { in } \\
\text { differenced } \\
\text { equations; } \\
\Delta(\mathrm{TRAIN})_{\mathrm{t}-2,} \\
\Delta \ln (\mathrm{Hrs} / \mathrm{N})_{\mathrm{t}-2} \\
\Delta \ln (\mathrm{K} / \mathrm{N})_{\mathrm{t}-2} \text { in the } \\
\text { levels equations. }\end{array}$ \\
\hline \multicolumn{5}{|c|}{ Unconstrained (COMFAC not imposed) } \\
\hline $\begin{array}{l}\text { Lagged dependent } \\
\text { variable }\end{array}$ & $\begin{array}{l}.543 \\
(.058)\end{array}$ & $\begin{array}{c}.599 \\
(.063)\end{array}$ & $\begin{array}{l}.707 \\
(.035)\end{array}$ & $\begin{array}{l}.624 \\
(.045)\end{array}$ \\
\hline Training $_{t}$ & $\begin{array}{c}.930 \\
(.465) \\
\end{array}$ & $\begin{array}{r}.652 \\
(.412) \\
\end{array}$ & $\begin{array}{l}.248 \\
(.165) \\
\end{array}$ & $\begin{array}{l}.302 \\
(.149) \\
\end{array}$ \\
\hline Training $_{\mathrm{t}-1}$ & $\begin{array}{l}.116 \\
(.265) \\
\end{array}$ & $\begin{array}{l}-.969 \\
(.648) \\
\end{array}$ & $\begin{array}{l}.085 \\
(.134) \\
\end{array}$ & $\begin{array}{l}.272 \\
(.289) \\
\end{array}$ \\
\hline $\log (\text { capital/worker })_{t}$ & $\begin{array}{c}.278 \\
(.073) \\
\end{array}$ & $\begin{array}{c}.323 \\
(.056) \\
\end{array}$ & $\begin{array}{c}.120 \\
(.051) \\
\end{array}$ & $\begin{array}{c}.028 \\
(.037) \\
\end{array}$ \\
\hline $\log (\text { capital/worker })_{\mathrm{t}-1}$ & $\begin{array}{l}-.156 \\
(.063) \\
\end{array}$ & $\begin{array}{l}-.104 \\
(.063) \\
\end{array}$ & $\begin{array}{l}-.078 \\
(.044) \\
\end{array}$ & $\begin{array}{l}.020 \\
(.033) \\
\end{array}$ \\
\hline $\log (\text { hours/worker) })_{t}$ & $\begin{array}{l}.495 \\
(.165) \\
\end{array}$ & $\begin{array}{c}.434 \\
(.123) \\
\end{array}$ & $\begin{array}{c}.359 \\
(.064) \\
\end{array}$ & $\begin{array}{c}.480 \\
(.079) \\
\end{array}$ \\
\hline $\log \left(\right.$ hours/worker) $\mathrm{t}-1_{1}$ & $\begin{array}{l}-.422 \\
(.232) \\
\end{array}$ & $\begin{array}{l}-.397 \\
(.169) \\
\end{array}$ & $\begin{array}{l}-.189 \\
(.114) \\
\end{array}$ & $\begin{array}{l}-.362 \\
(.100) \\
\end{array}$ \\
\hline $\begin{array}{l}\text { R\&D } \\
\text { Intensity }{ }_{t-1}\end{array}$ & $\begin{array}{l}1.248 \\
(.605)\end{array}$ & $\begin{array}{l}1.137 \\
(.669)\end{array}$ & $\begin{array}{l}.549 \\
(.323)\end{array}$ & $\begin{array}{l}.551 \\
(.334)\end{array}$ \\
\hline $\begin{array}{l}\text { R\&D } \\
\text { Intensity } t-2\end{array}$ & $\begin{array}{r}-1.157 \\
(.672) \\
\end{array}$ & $\begin{array}{l}-.671 \\
(.740) \\
\end{array}$ & $\begin{array}{l}-.493 \\
(.311) \\
\end{array}$ & $\begin{array}{c}.592 \\
(.354) \\
\end{array}$ \\
\hline $\begin{array}{l}\text { Managerial }_{\mathrm{t}} \\
\text { proportion }\end{array}$ & $\begin{array}{c}.446 \\
(.129) \\
\end{array}$ & $\begin{array}{l}.392 \\
(.136)\end{array}$ & $\begin{array}{l}.125 \\
(.056)\end{array}$ & $\begin{array}{l}.113 \\
(.070)\end{array}$ \\
\hline
\end{tabular}




\begin{tabular}{|l|l|l|l|l|}
\hline Managerial & -.148 & -.173 & -.044 & -.054 \\
proportion $_{\mathrm{t}-1}$ & $(.129)$ & $(.113)$ & $(.087)$ & $(.087)$ \\
\hline
\end{tabular}

\section{Notes}

These report a fuller set of results than those in Table 2 (which correspond to the first and last columns of Table B2). Estimation by GMM-SYS in Arellano and Bond (1998) DPD-98 package written in GAUSS; all regressions include the current values of all the variables in Table 2 columns (3) and (6) (i.e. turnover, other occupations, qualifications, age, tenure, gender, region, firm size and time dummies). Capital intensity, training, hours and lagged productivity are always treated as endogenous. The other variables are assumed weakly exogenous. One step standard errors (robust to arbitrary heteroskedacity and autocorrelation) in parentheses under coefficients; LM1(2) is a Lagrange Multiplier test of first (second) order serial correlation distributed N[1,0] under the null (see Arellano and Bond, 1991); Sargan is a Chi-squared test of the over-identifying restrictions; observations weighted by number of individuals in an LFS industry cell. 


\section{References}

ACEMOGLU, D. and ANGRIST, J. (2000) 'How large are the social returns to education? Evidence from compulsory schooling laws', NBER Macroeconomics Annual, 9-59

ACEMOGLU, D. and PISHKE, S. (1999), 'The Structure of Wages and Investment in General Training', Journal of Political Economy, 107, 539-572.

ACEMOGLU, D. and PISHKE, S. (2003), "Minimum Wages and On the Job Training" Research in Labor Economics, 22, 159-202

AGHION, P. and HOWITT, P. (1998), Endogenous Growth Theory, Cambridge, Mass.: MIT Press.

ARELLANO, M. and BOND, S. (1991), "Some tests of specification for panel data: Monte Carlo evidence and an application to employment equations" Review of Economic Studies, 58, 277-297

ARELLANO, M. and BOND, S. (1998) "Dynamic Panel Data Estimation using DPD for GAUSS", mimeo Institute for Fiscal Studies

BALLOT, G., FAKHFAKH, F. and TAYMAZ, E. (1998), "Formation continue, recherche et Développement, et performance des entreprises", Formation Emploi, 64, 43-55.

BALLOT, G., FAKHFAKH, F. and TAYMAZ, E. (2001), "Firms' human capital, R\&D and performance: a study on French and Swedish firms," Labour Economics, vol 8.

BALLOT, G., FAKHFAKH, F. and TAYMAZ, E. (2002), "Who benefits from training and R\&D: The firm or the workers?", ERC Working Papers in Economics 02/01, June.

BARRON, J. M., BLACK, D. A. and LOEWENSTEIN, M. A. (1989), "Job Matching and On-the-Job Training", Journal of Labour Economics, 7, 1, 1-19.

BARTEL, A. P. (1994), "Productivity Gains from the Implementation of Employee Training Programmes", Industrial Relations, 33, 411-425

BARTEL, A. P. (1995), "Training, Wage Growth, and Job Performance: Evidence from a Company Database", Journal of Labour Economics, 13, 3, 401-425.

BARTEL, A. AND SICHERMAN "Technological Change and Wages: An Interindustry Analysis" Journal of Political Economy 107: 285

BARRETT, A. AND O'CONNELL, P. (2001) "Does training generally work? The returns to in-company training" Industrial and Labor Relations Review, 54(3) 647-683

BLACK, S. E. and LYNCH, L.M. (1996), "Human-Capital Investments and Productivity", American Economic Review, 86, 2, 263-267. 
BLACK, S. E. and LYNCH, L.M. (2001), "How to Compete: The Impact of Workplace Practices and Information Technology on Productivity", Review of Economics and Statistics 83(3), 434-445

BLANCHFLOWER, D. and LYNCH, L. M. (1992), "Training at work: a comparison of US and British youths", London School of Economics, Centre for Economic Performance, Discussion Paper no. 78.

BLUNDELL, R. and BOND, S (1998) "Initial Conditions and Moment Restrictions in dynamic Panel Data Models" Journal of Econometrics, 87, 115-143

BLUNDELL, R. and BOND, S (2000) "GMM Estimation with Persistent Panel Data: An Application to production functions" Econometric Reviews 19(3), 321-340

BLUNDELL, R., DEARDEN, L. and MEGHIR, C. (1996), The Determinants of Work Related Training in Britain, London: Institute of Fiscal Studies.

BOOTH, A. (1991), "Job-related formal training: who receives it and what is it worth?", Oxford Bulletin of Economics and Statistics, 53, pp.281-94.

BOOTH, A. (1993), "Private sector training and graduate earnings", Review of Economics and Statistics, 75, pp. 164-70.

BOOTH, A., FRANCESCONI, M. and ZOEGA, G. (1999) 'Training, Rent Sharing and Unions', mimeo University of Essex

BOON, M. and VAN DER EIJKEN, B. "Employee Training and productivity in Dutch manufacturing firms" Statistics Netherlands, mimeo

CARD, D. (1999), "The Causal Effect of Education on Earnings", in Ashenfelter, O. and Card, D. (eds.), Handbook of Labour Economics, Elsevier, Amsterdam.

CARRIOU, Y. and JEGER, F (1997), "La Formation Continue Dans les Entreprises et son Retour sur Investissement", Economie et Statistique, 303, 45-58.

CONYON, M. and REED, L. (1999) "Survey on Human Resource Practices and Corporate Value in the Modern Corporation", Corporate Performance Unit, Warwick Business School and ESRC Data Archive

DEARDEN, L., REED, H. AND VAN REENEN, J. (2000) "Who gains when workers train? Training and corporate productivity in a panel of British Industries" Institute for Fiscal Studies Working Paper No. 00/04

DE KONING, J. (1994), "Evaluating Training at the Company Level", ch.7 in McNabb, R. and Whitfield, K. (eds.), The Market for Training, Aldershot: Avebury.

DELAME, E. and KRAMARZ, F. (1997) "Enterprises et formation continue" Economie et Prevision, vol 127

FELSTEAD, A., GREEN, F. and MAYHEW, K. (1997), Getting the Measure of Training, Leeds, Centre for Industrial Policy and Performance. 
GREEN, F. and STEEDMAN, H. (1997), Into the Twenty First Century: An Assessment of British Skill Profiles and Prospects, LSE Centre for Economic Performance, Special Report.

GREENHALGH, C. (2002), "Adult Vocational Training in France and Britain", Fiscal Studies, vol 23, no. 2, 223-263.

GREENHALGH, C. and STEWART, M. (1987), "The effects and determinants of training", Oxford Bulletin of Economics and Statistics, 49, 171-189.

GRILICHES (1992) "The Search for R\&D Spillovers" Scandinavian Journal of Economics 94, S29-S47

GRUNFELD, D. and GRILICHES, Z. (1960) 'Is Aggregation necessarily bad?' The Review of Economics and Statistics, XLII, 1, 1-13

HAEGELAND, T. AND KLETTE, T. (1999): Do higher wages reflect higher productivity? Education, gender and experience premiums in a matched plant-worker data set. In J. Haltiwanger, J.Lane, J.R Spletzer, J. Theeuwes and K. Troske (eds.): The creation and analysis of employer-employee matched data, North Holland Publ.Co.

HASKEL, J., HAWKES, D. AND PEREIRA, S. (2003) "Skills, productivity in the UK using matched establishment, worker and workforce data" Ceriba Discussion Paper, May.

HECKMAN, J., LOCHNER,L. and TODD, P. (2003) "Fifty Years of Mincer Earnings Regressions" NBER Working Paper No. 9732

HELLERSTEIN, J., NEUMARK, D. AND TROSKE, K. (1999) "Wages, Productivity and Worker Characteristics: Evidence from plant level production functions and wage equations" Journal of Labor Economics, Vol. 17, 3, 409-446

HELLERSTEIN, J. and NEUMARK, D. (1999) "Sex, wages and productivity: An empirical analysis of Israeli Firm level Data" International Economic Review, 40(1), 95-123

HOLZER, H., BLOCK, R., CHEATHAM AND KNOTT,J. (1993) "Are training subsidies for firms effective? (1990) "The determinants of employee productivity and earnings" Industrial and Labour Relations Review, 46, 625-636, 29, 3, 403-22

ICHNIOWSKI, SHAW, K. and PRENNUSHI, G. (1997), "The effects of human resource management practices on productivity", American Economic Review, 87, June, 291-313

JONES, P. (2001) "Are Educated Workers really more productive?" Journal of Development Economics, 64, 57-79

KRUEGER, A. and ROUSE, C. (1998) "The effects of workplace education on Earnings, Turnover and Job Performance" Journal of Labor Economics, $16,161-94$

LAZEAR, E. (1979), "Why is there mandatory retirement?" Journal of Political Economy, 87, December, pp. 1261-84. 
LILLARD, L. A. and TAN, H. W. (1992), "Private Sector Training: Who Gets It and What Are Its Effects?", Research in Labour Economics, 13, JAI Press, 1-62.

LYNCH, L. M. (1992) "Private sector training and the earnings of young workers", American Economic Review, vol. 82, pp. 299-312.

MACHIN, S. and VAN REENEN, J. (1998) "Technology and changes in the skill structure: Evidence from seven OECD countries" Quarterly Journal of Economics CXI, 443, 195-226

MACHIN, S., VIGNOLES, A. AND GALINDO-RUEDA (2003) "Sectoral and Area analysis of the Economic Effects of Qualifications and Basic Skills" Department for Education and skills Research Report RR465

MORETTI, E. (2004) "Workers' education, spillovers and productivity" American Economic Review, 94(3)

NATIONAL SKILLS TASK FORCE (1998), Towards a National Skills Agenda, Sudbury, Department for Education and Employment.

NICKELL, S.J. (1981) "Biases in dynamic models with fixed effects" Econometrica 49, 1417-1426

O'MAHONY, M. (1998) "Anglo-German Productivity differences: the role of broad capital" Bulletin of Economic Research, 50, 19-36

TAN, H. C., CHAPMAN, B., PETERSON, C. and BOOTH, A. (1992), "Youth training in the US, Britain and Australia", in Research in Labor Economics, vol. 13, pp. 63-99, JAI Press.

WINKELMANN, R. (1994), "Training, Earnings and Mobility in Germany", Centre for Economic Policy Research, Discussion Paper, No.982. 


\section{CENTRE FOR ECONOMIC PERFORMANCE Recent Discussion Papers}

673 Giulia Faggio Stephen Nickell

672 Chiara Criscuolo Ralf Martin

671 Roberto Torrini

670 Silvia Ardagna Francesco Caselli Timothy Lane

669 Alejandro Cuñat Marco Maffezzoli

668 Francesco Caselli Silvana Tenreyro

667 Francesco Caselli

666 Gianluca Benigno Pierpaolo Benigno

665 Olmo Silva

664 Maarten Goos

663 Christopher A. Pissarides Giovanna Vallanti

662 Philip R. Lane Gian Maria Milesi-Ferretti

661 Alex Bryson Lorenzo Cappellari Claudio Lucifora
Inactivity Among Prime Age Men in the UK

Multinationals and US Productivity Leadership: Evidence from Great Britain

Profit Share and Returns on Capital Stock in Italy: the Role of Privatisations Behind the Rise of the 1990s

Fiscal Discipline and the Cost of Public Debt Service: Some Estimates for OECD Countries

Can Comparative Advantage Explain the Growth of US Trade?

Is Poland the Next Spain?

Accounting for Cross-Country Income Differences

Designing Target Rules for International Monetary Policy Cooperation

Entrepreneurship: Can the Jack-of-All-Trades Attitude be Acquired?

Sinking the Blues: the Impact of Shop Closing Hours on Labor and Product Markets

Productivity Growth and Employment: Theory and Panel Estimates

Financial Globalization and Exchange Rates

Do Job Security Guarantees Work? 
660 David Marsden

Richard Belfield

659 Rachel Griffith

Rupert Harrison

John Van Reenen

658 Douglas Kruse

Richard B. Freeman

Joseph Blasi

Robert Buchele

Adria Scharf

Loren Rodgers

Chris Mackin

657 Christopher Crowe

656 James Banks

Richard Disney

Alan Duncan

John Van Reenen

655 Eran Yashiv

654 Hilary Steedman

Sheila Stoney

653 Ralf Martin

652 Jörn-Steffen Pischke

651 Anthony J. Venables

650
Unions, Performance-Related Pay and Procedural

Justice: the Case of Classroom Teachers

How Special is the Special Relationship? Using the Impact of R\&D Spillovers on UK Firms As a Test of Technology Sourcing

Motivating Employee Owners in ESOP Firms:

Human Resource Policies and Company Performance
Inflation, Inequality and Social Conflict

The Internationalisation of Public Welfare Policy
The Self Selection of Migrant Workers Revisited

Disengagement 14-16: Context and Evidence

Globalisation, ICT and the Nitty Gritty of Plant Level Datasets

Labor Market Institutions, Wages and Investment

Evaluating Urban Transport Improvements: Cost Benefit Analysis in the Presence of Agglomeration and Income Taxation

Is There a Market for Work Group Servers?

Evaluating Market Level Demand Elasticities Using

Micro and Macro Models

The Centre for Economic Performance Publications Unit Tel 02079557673 Fax $02079557595 \quad$ Email info@cep.lse.ac.uk Web site http://cep.Ise.ac.uk 